ANL-5972

Argonne \ational Laboratom

THERMAL EXPANSION OF, ALPHA-URANIUM SINGLE CRYSTALS

$$
\begin{aligned}
& \text { by } \\
& \text { L. T. Lloyd }
\end{aligned}
$$




\section{LEGAL NOTICE}

This report was prepared as an account of Government sponsored work. Neither the United States, nor the Commission, nor any person acting on behalf of the Commission:

A. Makes any warranty or representation, expressed or implied, with respect to the accuracy, completeness, or usefulness of the information contained in this report, or that the use of any information, apparatus, nethod, or process disclosed in this report may not infringe privately owned rights; or

B. Assumes any liabilities with respect to the use of, or for damages resulting from the use of any infomation, apparatus, method, or process disclosed in this report.

As used in the above, "person acting on behalf of the Commission" includes any employee or contractor of the Commission, or employee of such contractor, to the extent that such employee or contractor of the Commission, or employee of such contractor prepares, disseminates, or provides access to, any information pursuant to his employment or contract with the Commission, or his employment with such contractor.

Price \$1.50. Available from the Office of Technical Services, Department of Commerce, Washington 25, D.C. 


\section{DISCLAIMER}

This report was prepared as an account of work sponsored by an agency of the United States Government. Neither the United States Government nor any agency Thereof, nor any of their employees, makes any warranty, express or implied, or assumes any legal liability or responsibility for the accuracy, completeness, or usefulness of any information, apparatus, product, or process disclosed, or represents that its use would not infringe privately owned rights. Reference herein to any specific commercial product, process, or service by trade name, trademark, manufacturer, or otherwise does not necessarily constitute or imply its endorsement, recommendation, or favoring by the United States Government or any agency thereof. The views and opinions of authors expressed herein do not necessarily state or reflect those of the United States Government or any agency thereof. 


\section{DISCLAIMER}

Portions of this document may be illegible in electronic image products. Images are produced from the best available original document. 
ANL-5972

Metallurgy and Ceramics

(TID-4500, 14th Ed.)

AEC Research and

Development Report

\section{ARGONNE NATIONAL LABORATORY}

P. O. Box 299

Lemont, Illinois

THERMAL EXPANSION OF ALPHA-URANIUM SINGLE CRYSTALS

by

L. T. Lloyd

Metallurgy Division

Partial Report Metallurgy Program 4.1.6

June, 1959

Portions of the material in this report have appeared in the following Metallurgy Division Reports:

\begin{tabular}{ccl} 
Number & Page & \multicolumn{1}{c}{ Date } \\
\cline { 3 - 3 } ANL-5153 & $28-31$ & September, 1953 \\
ANL-5790 & $37-39$ & June, 1957 \\
ANL-5797 & $36-39$ & September, 1957 \\
ANL-5837 & Section V.1.a & December, 1957 \\
ANL-5975 & 49 & March, 1959
\end{tabular}

Operated by The University of Chicago

under

Contract W-31-109-eng-38 
TABLE OF CONTENTS

Page

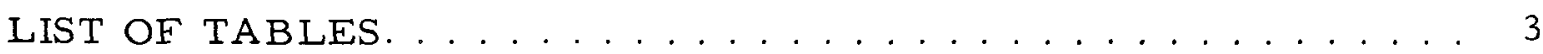

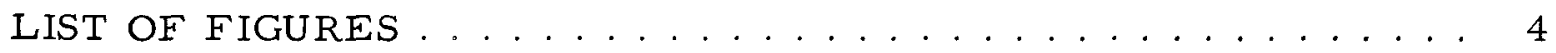

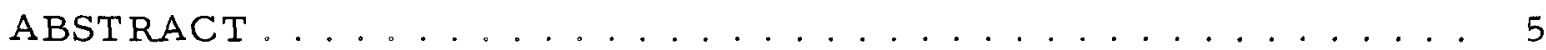

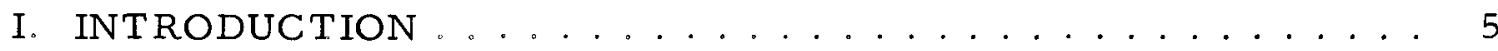

II. EXPERIMENTAL PROCEDURE ................ 6

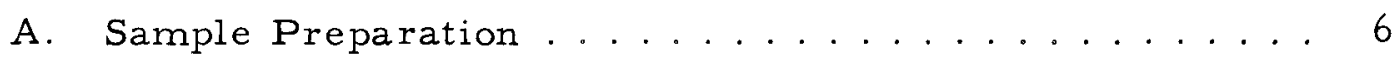

B. Dilatometric Measurements............. 7

C. Data Treatment................. 7

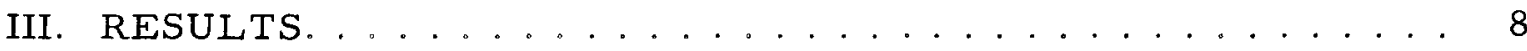

A. Equations Fitted to Lattice Parameter Data . . . . . . . 8

B. Thermal Expansion of Single Crystals .......... 10

1. Thermal expansion of crystals in the principal directions...................... 10

2. Thermal expansion of randomly oriented crystals ....................... 12

C. Mean Thermal Expansion Coefficients .......... 13

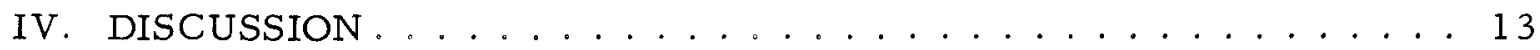

A. Comparison of Fraction Expansion Data......... 13

B. Comparison of Mean Thermal Expansion Coefficients... 14

C. Lattice Parameter Corrections Derived from Single Crystal Expansion Data................ 14

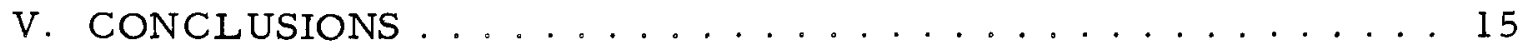

VI. ACKNOWLEDGEMENTS . . . . . . . . . . . . . . 15

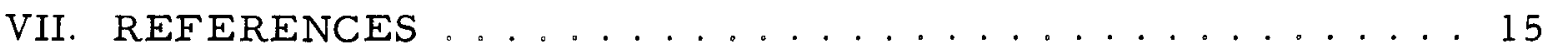




\section{LIST OF TABLES}

No.

$\underline{\text { Title }}$

$\underline{\text { Page }}$

I. Alpha-Uranium Lattice Parameter Data of Bridge, Schwartz and Vaughan ..................... 17

II. Alpha-Uranium Lattice Parameter Data of Chiotti, Klepfer

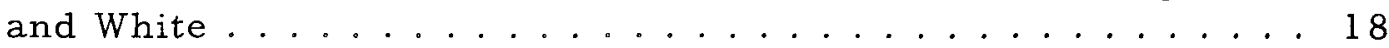

III. Thermal Expansion of Crystal $\mathrm{T}_{\mathrm{D}}$ in the [100] Direction . . . 19

IV. Alpha-Uranium Thermal Expansion in the [100] Direction . . 20

V. Alpha-Uranium Thermal Expansion in the [010] Direction . . 21

VI. Alpha-Uranium Thermal Expansion in the [001] Direction . . 22

VII. Volumetric Thermal Expansion of Alpha-Uranium ...... 23

VIII. Testing Directions and Initial Lengths of Randomly Oriented Crystals.................... 23

IX. Thermal Expansion of Crystal 219-2 ........... 24

X. Thermal Expansion of Crystal 235-B........... 25

XI. Thermal Expansion of Crystal 240-A . . . . . . . . 26

XII. Thermal Expansion of Crystal 240-B ............ 27

XIII. Thermal Expansion of Crystal 240-C ........... 28

XIV. Thermal Expansion of Crystal $\mathrm{T}_{\mathrm{G}} \ldots \ldots \ldots 29$

XV. Mean Thermal Expansion Coefficients of Alpha-Uranium in

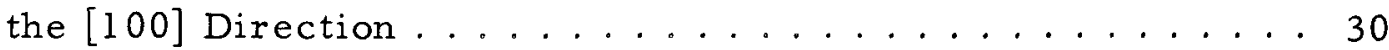

XVI. Mean Thermal Expansion Coefficients of Alpha-Uranium in

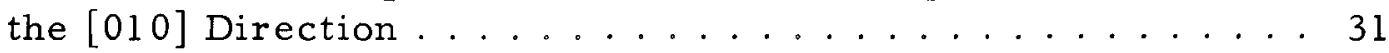

XVII. Mean Thermal Expansion Coefficients of Alpha-Uranium in

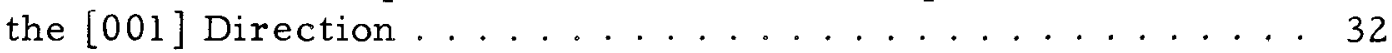

XVIII. Volumetric Mean Thermal Expansion Coefficients of

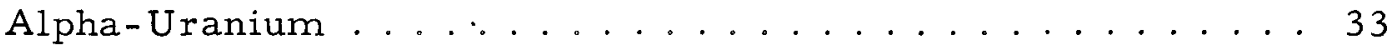

XIX. Corrected Alpha-Uranium Lattice Parameters at $25^{\circ} \mathrm{C} \ldots 34$ 


\section{LIST OF FIGURES}

No.

Title

$\underline{\text { Page }}$

1 Alpha-Uranium a Lattice Parameter Variation with

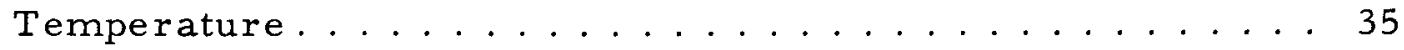

2 Alpha-Uranium bo Lattice Parameter Variation with

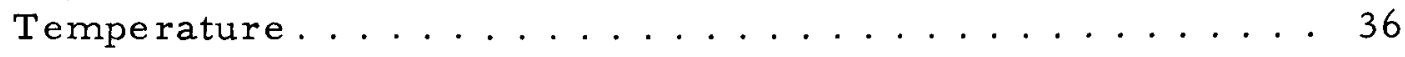

3 Alpha-Uranium $c_{0}$ Lattice Parameter Variation with

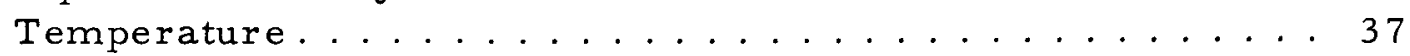

4 Alpha-Uranium Unit Cell Volume Variation with

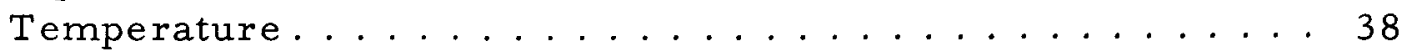

5 Thermal Expansion of Alpha-Uranium in the [100] Direction . 39

6 Thermal Expansion of Alpha-Uranium in the [010] Direction . 40

7 Thermal Expansion of Alpha-Uranium in the [001] Direction . 41

8 Volumetric Thermal Expansion of Alpha-Uranium . . . . . 42

9 Thermal Expansion of Crystal 219-2 .......... 43

10 Thermal Expansion of Crystal 235-B........... 44

11 Thermal Expansion of Crystal 240-A........... 45

12 Thermal Expansion of Crystal 240-B ........... 46

13 Thermal Expansion of Crystal 240-C . . . . . . . . 47

14 Thermal Expansion of Crystal $\mathrm{T}_{\mathrm{G}} \ldots \ldots \ldots$ 


\title{
THERMAL EXPANSION OF ALPHA-URANIUM SINGLE CRYSTALS
}

L. T. Lloyd

\begin{abstract}
Dilatometric measurements have been obtained between $25^{\circ}$ and $650^{\circ} \mathrm{C}$ from alpha-uranium single crystals in the three principal crystallographic directions. Least mean square fitted equations representing these directions and volume as functions of temperature $\left(t^{\circ} \mathrm{C}\right)$ are as follows:

$$
\begin{aligned}
& L_{[100]_{t}}=L_{[100]_{0}{ }^{\circ} \mathrm{C}}\left(1+23.53 \times 10^{-6} t+13.74 \times 10^{-9} t^{2}+9.94 \times 10^{-12} t^{3}\right) \\
& \left.\mathrm{L}_{[010}\right]_{\mathrm{t}}=\mathrm{L}_{[010]_{0} \mathrm{C}}\left(1+1.16 \times 10^{-6} \mathrm{t}-9.43 \times 10^{-9} \mathrm{t}^{2}-11.79 \times 10^{-12} \mathrm{t}^{3}\right) \\
& L[001]_{t}=L[001]_{0}{ }^{\circ}\left(1+19.38 \times 10^{-6} t+21.58 \times 10^{-9} t^{2}+3.32 \times 10^{-12} t^{3}\right) \\
& V_{t}=V_{0^{\circ} \mathrm{C}}\left(1+43.98 \times 10^{-6} t+26.88 \times 10^{-9} t^{2}+1.00 \times 10^{-12} t^{3}\right)
\end{aligned}
$$

Comparisons of fraction expansions of single crystals with those derived from lattice parameter measurements indicate that portions of the latter data are subject to errors because of elastic interactions between grains of polycrystalline samples.
\end{abstract}

\section{INTRODUCTION}

To understand some of the phenomena observed in alpha-uranium, it is necessary to know its expansion with temperature. Also, this information is basic to other physical property measurements. Since the lattice structure is orthorhombic, alpha-uranium has different thermal expansions for the three principal crystal axes; consequently, these values can not be measured directly from polycrystalline materials.

Thermal expansions for the principal directions have been derived from lattice parameter measurements of polycrystalline samples at various temperatures as reported by Bridge, Schwartz and Vaughan,(1) Chiotti, Klepfer and White(2) and Konobeevsky et al. (3) Thermal cycling studies have shown that polycrystalline alpha-uranium $(4)$ is subject to gross plastic deformations upon heating and cooling as well as to residual elastic strains. Since the lattice parameter studies were performed with polycrystalline samples, elastic strains may have been present and the observed lattice parameters could be in error. Likewise, the derived expansions could be incorrect. 
Single crystal expansion measurements obviously are not subject to errors introduced by elastic strains associated with grain interactions, and they should yield true expansion data. Measurements of this type have been reported by Lehr and Langeron $(5,6)$ for alpha-uranium "single crystals" grown by cooling in a temperature gradient through the $\beta$ to $\alpha$ transformation. $(7,8,9)$ Samples prepared in this manner contain lineage structure and are not truly single crystals. Their studies were of randomly oriented "crystals"; consequently, measurements were not made specifically along the principal crystal axes although they did derive mean thermal expansion coefficients for these directions.

A technique has been developed for preparing alpha-uranium single crystals that do not contain lineage structures. These are of sufficient size to permit preparation of two parallel surfaces of specific crystallographic orientation, and their expansion with temperature can be measured by dilatometric techniques. This report describes single crystal dilatation measurements and compares the results to previous data.

\section{EXPERIMENTAL PROCEDURES}

\section{A. Sample Preparation}

Alpha-uranium single crystals were obtained by the grain coarsening technique described by Fisher.(10) Their sizes, as-grown, ranged up to $0.200^{\prime \prime}$ in diameter and approximately $1 / 2 "$ in length. They were isolated from other grains and oriented for metallographic polishing according to techniques described by Lloyd and Chiswik.(11) Two parallel surfaces perpendicular to the original sample's axis were ciereloped on the randomly oriented crystals; these defined the crystallographic direction whose dilatation was measured. The samples for principal axes expansion measurements were prepared in the form of pseudo-unit cells with six flat surfaces parallel to the principal crystallographic planes.

Polished surfaces were prepared by normal metallographic techniques of grinding on water lubricated, rotating, silicon carbide papers through 600 mesh, polishing on rotating cloth laps with 3 and 1 micron diamond paste abrasive and electropolishing in a solution of 5 parts $85 \%$ orthophosphoric acid, 5 parts ethylene glycol and 8 parts ethyl alcohol at a current density of 30 milliamperes per square centimeter for approximately 10 minutes with a stainless steel cathode and a platinum touch wire. Particular care was taken during these operations so as not to plastically deform the body of the crystals and to minimize the distorted material created during metallographic preparation. In all cases, the thin layer of distorted material was removed by the final electropolish. The surfaces were then carefully observed metallographically and notations were made with regard to the quantity and location of twins and, in a few instances, very fine occluded grains. The crystallographic orientations of the crystals were determined by normal Laue backreflection techniques. (12) 
B. Dilatometric Measurements

Single crystal dilatations with temperature were measured with a Recording Quartz Differential Dilatometer.(13) Each crystal's original length was determined after electropolishing and just prior to testing to the nearest thousandth of a centimeter with a comparator located in a room of known, constant temperature; at least four measurements were made for each crystal and the recorded lengths are the average of these. The individual crystal was placed into the specimen sleeve of the dilatometer's quartz assembly and quartz "shims" were used to make up the total one inch length provided for specimens. The $\mathrm{Pt} / \mathrm{Pt}-10 \% \mathrm{Rh}$ temperature measuring thermocouple was placed immediately adjacent to one of the crystal's surfaces. Dilatation curves were obtained with the $\mathrm{H}^{\prime}$ scale of the dilatometer between room temperature and $650^{\circ} \mathrm{C}$ at heating and cooling rates of approximateiy $4^{\circ} \mathrm{C} / \mathrm{min}$. Each crystal was tested several times and expansion data were taken from reproducible curves. After testing the very thin corrosion product film was removed from the crystal by electropolishing and the surfaces were again observed metallographically.

\section{Data Treatment}

Single crystal expansion data were read from the dilatation curves at $25^{\circ} \mathrm{C}$ intervals over the range from $25^{\circ}$ to $650^{\circ} \mathrm{C}$. These data were then multiplied by the appropriate factor for the $\mathrm{H}^{\prime}$ scale, corrected for the expansion of the dilatometer's quartz components and normalized to represent fraction expansion based upon $25^{\circ} \mathrm{C}$ according to the procedure described in a later part of this report.

Average values of expansior for each $25^{\circ} \mathrm{C}$ interval and each principal direction were determined from the dilatation data of the crystals tested along the principal axes. These data were then submitted to an IBM 704 computer for least square polynomial fitting to equations of the type:

$$
\mathrm{Y}=\mathrm{k}_{0} \mathrm{X}^{0}+\mathrm{k}_{1} \mathrm{X}^{\mathrm{l}}+\cdots \cdots \cdot \mathrm{k}_{\mathrm{p}} \mathrm{X}^{\mathrm{p}}
$$

where: $Y$ represents the dimension at temperature $X_{0}, k_{0}, k_{l} \cdots \cdots k_{p}$ are constants and $\mathrm{p}$ is the order of the polynomial. In all cases equations were determined for p equals 1,2 and 3 . The best fit for each set of data was selected as the equation giving the lowest standard deviation ( $\sigma$ ) according to the equation:

$$
\sigma=\frac{\sum_{i=1}^{N}\left|R_{i}\right|}{N} \sqrt{\frac{\pi}{2}} .
$$


where: $N$ is the number of observations and $R_{i}$ is the difference between the observed and calculated $i$ th datum point. The experimental lattice parameters of Bridge, Schwartz and Vaughan(l) and Chiotti, Klepfer and White $(2)$ also were submitted to this type of equation fitting.

The data obtained from the randomly oriented crystals were compared to values for their expansion as calculated from single crystal and lattice parameter expansions in the principal directions according to the relationship:

$$
\begin{aligned}
\left(\frac{L_{t}{ }^{\circ} \mathrm{C}}{L_{25^{\circ} \mathrm{C}} L_{25^{\circ} \mathrm{C}}}\right)= & \left(\frac{L_{t^{\circ} \mathrm{C}}-\mathrm{L}_{25^{\circ} \mathrm{C}}}{\mathrm{L}_{25^{\circ} \mathrm{C}}}\right)_{[100]} \cos ^{2} \alpha \\
& +\left(\frac{\mathrm{L}_{t^{\circ} \mathrm{C}}-\mathrm{L}_{25^{\circ} \mathrm{C}}}{\mathrm{L}_{25^{\circ} \mathrm{C}}}\right)_{[010]}^{\cos ^{2} \beta} \\
& +\left(\frac{\mathrm{L}_{t^{\circ} \mathrm{C}}-\mathrm{L}_{25^{\circ} \mathrm{C}}}{\mathrm{L}_{25^{\circ} \mathrm{C}}}\right)_{[001]}^{\cos ^{2} \gamma}
\end{aligned}
$$

where: $\left(\frac{\mathrm{L}_{t^{\circ} \mathrm{C}}-\mathrm{L}_{25^{\circ} \mathrm{C}}}{\mathrm{L}_{25^{\circ} \mathrm{C}} \mathrm{C}}\right)$ is the fraction expansion in a given crystallographic direction upon going from $25^{\circ} \mathrm{C}$ to $t^{\circ} \mathrm{C},\left(\frac{\mathrm{L}_{\mathrm{t}}{ }^{\circ} \mathrm{C}-\mathrm{L}_{25^{\circ} \mathrm{C}}}{\mathrm{L}_{25^{\circ} \mathrm{C}}}\right)_{[100]}$,

$\left(\frac{\mathrm{L}_{t}{ }^{\circ} \mathrm{C}-\mathrm{L}_{25^{\circ} \mathrm{C}}}{\mathrm{L}_{25^{\circ} \mathrm{C}}}\right)_{[010]}$ and $\left(\frac{\mathrm{L}_{t^{\circ} \mathrm{C}}-\mathrm{L}_{25^{\circ} \mathrm{C}}}{\mathrm{L}_{25^{\circ} \mathrm{C}}}\right)_{[001]}$ are the fraction expansions

in the indicated principal directions over the same temperature range and $\alpha, \beta$ and $\gamma$ are the angles at $25^{\circ} \mathrm{C}$ between the given direction and the principal directions [100], [010] and [001], respectively. This relationship is the one usually presented in mathematical treatments of thermal expansion (see for example reference 14) for calculating the dilatation with temperature of a random crystallographic direction. Its derivation involves neglecting the second powers of the relatively small fraction expansions and, therefore, it does not yield precise values for randomly oriented alphauranium single crystals. The magnitudes of the errors introduced by this simplifying assumption for the randomly oriented crystals considered here, however, are less than the accuracy of the dilatometer used for the measurements.

\section{RESULTS}

\section{A. Equations Fitted to Lattice Parameter Data}

The $a_{0}, b_{0}, c_{0}$ and unit cell volume (V) lattice parameter data of Bridge, Schwartz and Vaughan (1) are plotted in Figures 1, 2, 3 and 4, respectively; both experimental points and fitted curves are shown. The 
experimental data are tabulated in Table I together with the difference between the observed and calculated values derived from the following fitted equations:

$$
\begin{aligned}
& \mathrm{a}_{0 \mathrm{~T}}=2.8353\left(1+19.50 \times 10^{-6} \mathrm{~T}-0.44 \times 10^{-9} \mathrm{~T}^{2}+15.06 \times 10^{-12} \mathrm{~T}^{3}\right) \\
& \mathrm{b}_{0 \mathrm{~T}}=5.8673\left(1-2.18 \times 10^{-6} \mathrm{~T}+12.55 \times 10^{-9} \mathrm{~T}^{2}-18.15 \times 10^{-12} \mathrm{~T}^{3}\right) \\
& \mathrm{c}_{0 \mathrm{~T}}=4.9276\left(1+21.75 \times 10^{-6} \mathrm{~T}-13.90 \times 10^{-9} \mathrm{~T}^{2}+23.72 \times 10^{-12} \mathrm{~T}^{3}\right) \\
& \mathrm{V}_{\mathrm{T}}=81.975\left(1+36.32 \times 10^{-6} \mathrm{~T}+6.95 \times 10^{-9} \mathrm{~T}^{2}+14.74 \times 10^{-12} \mathrm{~T}^{3}\right)
\end{aligned}
$$

where: $a_{0}, b_{0}, c_{0}$ and $V$ are the lattice dimensions and $T$ is expressed in ${ }^{\circ} \mathrm{K}$. The anomalous datum point at $20^{\circ} \mathrm{K}$ for the $\mathrm{a}_{0}$ was considered as a normal point in deriving the $\mathrm{a}_{0}$ and $\mathrm{V}$ equations.

By a simple reference temperature transformation to ${ }^{\circ} \mathrm{C}(\mathrm{t})$ the equations become:

$$
\begin{aligned}
& a_{0 t}=2.8512\left(1+22.50 \times 10^{-6} t+11.83 \times 10^{-9} t^{2}+14.98 \times 10^{-12} t^{3}\right) \\
& b_{0 t}=5.8671\left(1+0.61 \times 10^{-6} t-2.32 \times 10^{-9} t^{2}-18.15 \times 10^{-12} t^{3}\right) \\
& c_{0 t}=4.9542\left(1+19.36 \times 10^{-6} t+5.50 \times 15^{-9} t^{2}+23.60 \times 10^{-12} t^{3}\right) \\
& v_{t}=82.855\left(1+42.95 \times 10^{-6} t+18.82 \times 10^{-9} t^{2}+14.59 \times 10^{-12} t^{3}\right)
\end{aligned}
$$

Both sets of equations can be converted to express lengths in the principal directions and volume as functions of temperature and the respective values at the zero temperature by substituting $\mathrm{L}_{\text {[100], }}$ [010] and $L_{[001]}$ for $a_{0}, b_{0}$ and $c_{0}$ plus the respective lengths and volumes at zero temperature for the appropriate $a_{0}, b_{0}, c_{0}$ and $V$ values. For example, the $a_{0}$ equation for ${ }^{\circ} \mathrm{K}$ becomes:

$$
\mathrm{L}_{[100]_{\mathrm{T}}}=\mathrm{L}_{[100]_{0} \mathrm{~K}}\left(1+19.50 \times 10^{-6} \mathrm{~T}-0.44 \times 10^{-9} \mathrm{~T}^{2}+15.06 \times 10^{-12} \mathrm{~T}^{3}\right)
$$

for length in the [100] direction.

Figures 1, 2, 3 and 4 also plot the lattice parameter data of Chiotti, Klepfer and White(2) together with the fitted curves. Table II records their experimental data and the differences between these and values calculated from the following fitted equations:

$$
\begin{aligned}
& a_{0 t}=2.8522\left(1+18.51 \times 10^{-6} t+25.62 \times 10^{-9} t^{2}\right) \\
& b_{0 t}=5.8648\left(1-0.66 \times 10^{-6} t+7.59 \times 10^{-9} t^{2}-30.07 \times 10^{-12} t^{3}\right)
\end{aligned}
$$




$$
\begin{aligned}
& c_{0 t}=4.9522\left(1+15.11 \times 10^{-6} t+23.70 \times 10^{-9} t^{2}\right) \\
& V_{t}=82.838\left(1+32.62 \times 10^{-6} t+58.85 \times 10^{-9} t^{2}-31.52 \times 10^{-12} t^{3}\right)
\end{aligned}
$$

Finally, Figures 1, 2 and 3 include the curves of lattice parameter as a function of temperature between $0^{\circ}-500^{\circ} \mathrm{C}$ represented by the equations:

$$
\begin{aligned}
& a_{0 t}=2.8522\left(1+21.7 \times 10^{-6} t+22 \times 10^{-9} t^{2}\right) \\
& b_{0 t}=5.8650\left(1+8.5 \times 10^{-6} t-28 \times 10^{-9} t^{2}\right) \\
& c_{0 t}=4.9536\left(1+16.7 \times 10^{-6} t+21 \times 10^{-9} t^{2}\right)
\end{aligned}
$$

reported by Konobeevsky et al. (3) The volume curve calculated from the derived lattice parameters as a function of temperature is shown in Figure 4.

B. Thermal Expansion of Single Crystals

The thermal expansions of 12 alpha-uranium single crystals were determined during the course of the present work. Six of these were used for measurements along the principal axes and the remainder were tested in random directions. With one exception, metallographic observations indicated that only slight changes occurred during heating and cooling. In the case of specimen $\mathrm{T}_{\mathrm{E}}$, measured in the [100] direction, recrystallized grains were found after dilatation testing; therefore, its data have been neglected. In the other crystals a few twins were present prior to the measurements, but the majority of these were absorbed during the first tests and subsequent expansion curves for each crystal were reproducible and essentially unaffected by the remaining small fraction of twinned material. The origin of the twins can be ascribed to stresses associated with other grains affixed to the crystal during cooling from the grain coarsening treatment of the single crystal growth technique. All of the crystals had a thin corrosion product film subsequent to the dilatation testing; however, its thickness was not sufficient to significantly change the crystal's length and it was easily removed by short time electropolishing.

1. Thermal expansion of crystals in the principal directions: Seven dilatation measurements in directions within $0.5^{\circ}$ of the principal crystallographic axes were obtained from 5 pseudo-unit cell single crystals; two crystals were measured in two different principal directions. Two determinations were made of expansion in the [100], three in the $[010]$ and two in the $[001]$.

Table III illustrates the method of treating the data read from experimental expansion curves by converting it to measured expansion of the specimen, correcting for the expansion of quartz components in the dilatometer and normalizing to represent fraction expansion between $25^{\circ} \mathrm{C}$ 
and $t^{\circ} \mathrm{C}$. The indicated dilatation of the crystal $\left(\Delta \mathrm{L}_{\mathrm{E}}\right)$ was read from the $\mathrm{Y}$ coordinate of the experimental curve at intervals of $25^{\circ} \mathrm{C}$ in terms of $1 / 3^{11}$ to the nearest 0.05 portion thereof These figures were multiplied by the magnification factor of the dilatometer scale $\left(H^{\circ}\right.$ scale, $1 / 3^{\prime \prime}=$ $1.303 \times 10^{-4}$ inch dilatation) and added to the sample's original length at the reference temperature to yield the indicated length ( $L_{\mathrm{E}}$ ) of the crystal at $t^{\circ} \mathrm{C}$. The data were then multiplied by the correction factor $\left(K_{t}\right)$ representing the length of a piece of fused quartz at the respective temperature whose length at the reference temperature was exactly one inch. This correction has been discussed in greater detail by Lloyd. (13) The quartz length values as a function of temperature were determined from the data reported by Souder and Hidnert.(15) The crystal length values $\left(L_{t}\right)$ were then converted to fraction expansion by the relationship $\left(\frac{L_{t}{ }^{\circ} \mathrm{C}-L_{25^{\circ}} \mathrm{C}}{L_{25^{\circ} \mathrm{C}}}\right)$. Treating the data in this manner refers it to a constant reference temperature of $25^{\circ} \mathrm{C}$ and permits comparison with other data normalized in the same way. Subsequent use of the term expansion will in fact refer to fraction expansion.

The data for the three prircipal crystallographic directions as determined from the experimental curves in the above manner are given in Tables IV, $\mathrm{V}$ and VI. The tables also include expansions derived from the lattice parameter measurements of Bridge et al.(1) and Chiotti et al. (2) Finally, the tables give the averages for the single crystal expansion measurements and the differences between these and those calculated from the following least mean square fitted equations:

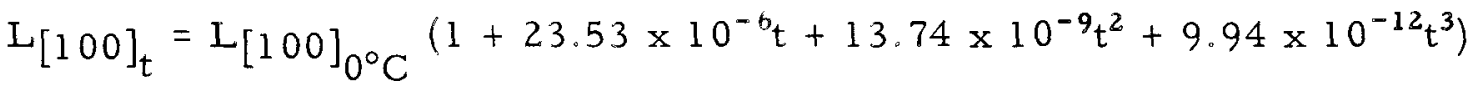

$$
\begin{aligned}
& L[010]_{t}=L[010]_{0^{\circ} \mathrm{C}}\left(1+1.16 \times 10^{-6} \mathrm{t}-9.43 \times 10^{-9} \mathrm{t}^{2}-11.79 \times 10^{-12} \mathrm{t}^{3}\right) \\
& \left.\mathrm{L}_{[001]_{\mathrm{t}}}=\mathrm{L}_{[001}\right]_{0^{\circ} \mathrm{C}}\left(1+19.38 \times 10^{-6} \mathrm{t}+21.58 \times 10^{-9} \mathrm{t}^{2}+3.32 \times 10^{-12} \mathrm{t}^{3}\right)
\end{aligned}
$$

Figures 5, 6 and 7 compare the the rmal expansions of the principal crystallographic directions. Each figure contains curves derived from the lattice parameter data of Bridge et al. and Chiotti et al. plus the curve for the average of the single crystal experimental data. The single crystal results agree well with the curves from lattice parameter data for the [100] direction expansion, whereas the single crystal [010] curve falls below the lattice parameter curves and the [001] falls above.

Table VII gives volume expansion data similar to that for the principal directions. The single crystal values were obtained by taking the product of the three principaldirection lengths, based upon a one inch 
length at $25^{\circ} \mathrm{C}$, at the respective temperatures and converting these to reppresent fraction volume expansion by the relationship: $\left(\frac{V_{t}{ }^{\circ} \mathrm{C}-V_{25^{\circ}} \mathrm{C}}{\mathrm{V}_{25^{\circ} \mathrm{C}}}\right)$. The equation fitted to these data by least mean square analysis is:

$$
V_{t}=V_{0^{\circ}} \mathrm{C}\left(1+43.98 \times 10^{-6} t+26.88 \times 10^{-9} t^{2}+1.00 \times 10^{-12} t^{3}\right)
$$

Figure 8 gives the curve for the single crystal volume expansion equation and compares it to similar curves from the data of Bridge et al. and Chiotti et al; in this case the data agree reasonably well.

2. Thermal expansion of randomly oriented crystals: The testing directions for the six randomly oriented crystals, as determined by Laue back-reflection photograms, are tabulated in Table VIII together with their initial lengths measured at the indicated temperatures. The angular values are accurate within 0.5 degrees. Tables IX, X, XI, XII, XIII and XIV record the experimental expansions after applying the necessary magnification factor and quartz correction and converting them to represent fraction expansions. As was indicated above, if a crystal's orientation is known its expansion can be calculated by a squared direction cosine relationship of the principal direction expansions. Each table contains values determined in this manner using principal direction expansions derived from least mean square fitted equations of the lattice parameter data of Bridge et al. and Chiotti et al. and dilatation measurements of single crystals. Figures $9,10,11,12,13$ and 14 are the plots of measured and calculated expansions for the randomly oriented crystals. The curves calculated from the principal direction expansions derived from the data of Chiotti et al. have not been included in the figures since the values given in the tables show that they would lie above the curves calculated from the data of Bridge et al.

The experimental curves for two of the crystals, 219-2 and 235-B, agree quite well with the expansions calculated from single crystal principal direction data. Two others, $240 \mathrm{C}$ and $\mathrm{T}_{\mathrm{G}}$, agree better with the single crystal calculated curves than they do with the curves calculated from the data of Bridge et al. The remaining two crystals, $240 \mathrm{~A}$ and $240 \mathrm{~B}$, show poor agreement with single crystal calculated curves, particularly, $240 \mathrm{~A}$ which even lies above the lattice parameter data curve.

The deviations of the experimental curves from those calculated using the single crystal principal direction expansions suggest that the particular randomly oriented crystal may contain significant quantities of differently oriented material. It may be noted that the two crystals which showed poor agreement and one of those showing fair agreement are from the same source metal (240). All three of these crystals contain appreciable twins prior to testing whereas the other three did not. Some of the twins in 
the 240 crystals persisted after testing and their presence could well explain the poorer agreement with the curves calculated from single crystal principal direction expansions. In any event, it is significant to note that five of the six experimental curves fall below those calculated from the data of Bridge et al.

C. Mean Thermal Expansion Coefficients

Another method of reporting thermal expansion is to give the mean coefficients between a reference temperature and $t^{\circ} \mathrm{C}$. Tables $X V, X V I$, XVII and XVIII record these values for the principal direction and volume thermal expansions of alpha-uranium. The $20^{\circ} \mathrm{C}$ reference temperature was chosen to permit direct comparison of the values with data reported by Lehr and Langeron. $(5,6)$ Each table contains mean thermal expansion coefficients calculated from the equations obtained by least mean square fitting of the lattice parameter data reported by Bridge et al.(1) and Chiotti et al. (2) and of single crystal measurements plus the previously reported coefficients.

\section{DISCUSSION}

\section{A. Comparison of Fraction Expansion Data}

Figures 1, 2, 3 and 4 show the fair agreement between the lattice parameters reported by Bridge et al.(1) and Chiotti et al..(2) however. the values calculated from the equations reported by Konobeevsky et al. (3) do not agree as well. Undoubtedly, the works of the first two groups of investigators are more nearly correct than that of the last group.

The thermal expansions obtained from dilatometric measurements of single crystals are somewhat different thas those derived from the lattice parameter data, namely with regard to the expansion found for the [010] and [001] directions (Figures 6and 7). It is believed that these differences are caused by elastic strains in the polycrystalline samples employed for the lattice parameter measurements. In effect, these strains prevented the [010] direction from contracting as much as it should and, in opposition, they prevented the [001] direction from expanding.

Three aspects of the data presented herein support this viewpoint. The first is the fair agreement found for the volumetric expansions as derived from the three groups of data (Figure 8). If the restraints associated with the lattice parameter data were not elastic the re could be appreciable differences between the lattice parameter volumetric expansions and the single crystal expansion. This volumetric expansion agreement substantiates the internal validity of each data group. Secondly, the 
association of elastic restraints with grain interactions is supported by a comparison of the single crystal expansions with those derived from the two sets of lattice parameter data. In both instances the restraining effect associated with the lattice parameter data of Chiotti et al. (2) is greater than that indicated from the data of Bridge et al. (1) (Figures 6 and 7). This is what might be expected since Chiotti et al. used massive samples for their measurements and Bridge et al. used more funelv divided material in the form of filings; undoubtedly, the elastic restraints in a massive polycrystalline sample would be greater than those in polycrystalline filings. Finally, the over-all better agreement between observed and calculated expansions of randomly oriented crystals (Figures 9,10,11,12,13 and 14) as determined from the single crystal principal direction expansions indicates that these data are more valid than the lattice parameter data.

\section{B. Comparison of Mean Expansion Coefficients}

The mean thermal expansion coeff-cients given ir. Tables XV, XVI, XVII and XVIII, of course, bear out the above observations wath regard to comparisons of lattice parameter expansions with those of sir.gle cry tals. The somewhat superior quality of the data of Bridge et al. over that of Chiotti et al. is substantiated by the better agreement found for the former when compared to the single crystal mean expansion roefficients for volume and the [100] direction. The mean thermal expansuon sefficients previously reported by Lehr and Langeron $(5,6)$ do not show consistent variations with regard to the single crystal data

\section{Lattice Parameter Corrections Derıved from Single Crystal Expansion Data}

Unfortunately the single crystal expansion data cannot be used to precisely correct the previously reported lattice parameters. Since expansion is a relative measure, the true iattice parameters at some tem. perature would have to be known before such corrections could be applied. There is no means of determining the temperature where the elastic restraints associated with the previous ry reported lattice parameter data are zero or at least a minimum: however, intuitivelv they should $\mathrm{k}$ e a minimum at high alpha temperatures. If it is assumed that the lattice parameters at $650^{\circ} \mathrm{C}$, as determined from the data of Bridge et al., are not subject to elastic restraints, then the corrected lattice parameters shown in Table XIX can be calculated from the single crystal expansion data. Comparison of the calculated values with those derived from least mean square fitted equations for the data of Bridge et al. again shows good agreement between $a_{0}$ and unit cell volume values, whereas $b_{0}$ and $c_{0}$ differ significantly. The $b_{0}$ lattice parameter calculated from the single crystal expansion is $0.0047 \AA$ greater than the value derived from the lattice parameter data and $c_{0}$ is $0.0059 \AA$ smaller. These differences 
are considerably greater than the indicated $\pm 0.0005 \AA$ accuracy for the lattice parameter measurements and they are greater than the standard deviation for the fitted equations. In view of the present results, it appears that accurate lattice parameters of alpha-uranium cannot be obtained from polycrystalline samples, and only single crystals, not subject to internal elastic strains, can be used to obtain such data.

\section{CONCLUSIONS}

Thermal expansion measurements performed on alpha-uranium single crystals of known orientation indicate that previously reported lattice parameters obtained from polycrystalline samples are subject to errors because of elastic interactions between grains. Contraction in the [010] direction is restrained by the interactions as is expansion in the [001] direction. Single crystal and lattice parameter data for volumetric expansion and expansion in the [100] direction agree well. Equations representing expansion in the three principal directions and volumetric expansion as derived from single crystal dilatation measurements are given in the report.

\section{ACKNOW LEDGEMENTS}

This work was carried out under the direction of F. G. Foote and H. H. Chiswik. The author would like to acknowledge the assistance of J. L. Walker in performing some of the dilatometric measurements. In addition, the author is extremely grateful to $M$. D. Odie who so carefully prepared the small single crystal specimens.

\section{REFERENCES}

1. Bridge, J. R., Schwartz, C. M. and Vaughan, D. A., "X-Ray Diffraction Determination of the Coefficients of Expansion of Alpha-Uranium," Trans. AIME (1956) 206, $1282-1285$.

2. Chiotti, P., Klepfer, H. H. and White, R. W., "Lattice Parameters of Uranium from $25^{\circ}$ to $1132^{\circ} \mathrm{C}$, to be published in Trans. ASM (1959).

3. Konobeevsky, S. T., Zaimovky, A. S., Levitsky, B. M., Sokursky, Y. N., Chebolarev, N. T., Bobkov, Y. V., Egorov, P. P., Nikolaev, G N., and Ivanov, A. A., "Some Physical Properties of Uranium, Plutonium and Their Alloys," Second United Nations International Conference on the Peaceful Uses of Atomic Energy, A/Conf. 15/P/2230, U.S.S.R., 7 July, 1958. 
4. See for example the group of papers in Transactions ASM (1958) 50

Zegler, S. T., Mayfield, R. M. and Mueller, M. H., "Effects of Fabrication and Heat Treatment Variables upon the Thermal Cycling Behavior of Uranium," pp. 905-925.

Mayfield, R. M., "Effect of Cycling Variables upon Growth Rates of $300^{\circ} \mathrm{C}$ Rolled Uranium," pp. 926-942.

Burke, J. E. and Turkalo, A. E., "The Growth of Uranium upon Thermal Cycling," pp. 943-953.

Lloyd, L. T. and Mayfield, R. M., "Microstructural Changes of Uranium upon Thermal Cycling," pp. 954-980.

5. Lehr, P. and Langeron, J. P., "Dilatometric Study of Uranium in the Alpha Phase," Revue de Metallurgie (1957) 54, 257-269.

6. Lehr, P. and Langeron, J. P., "Dilatometric Behavior of Alpha-Uranium Single Crystals," Comptes rendus (1955) 241, 1130-1133.

7. Cahn, R. W., "The Preparation of Alpha-Uranium Crystals," Acta Metallurgica (1953) $1,176-184$.

8. Lehr, P., "Preparation of Large Crystals of Uranium by Phase Change," Comptes rendus (1955) 241, 1043.

9. Fisher, E. S., "Preparation of Alpha Uranium Single Crystals, Part I Phase Transformation Method," ANL 5159, November 18, 1953.

10. Fisher, E. S., "Preparation of Alpha Uranium Single Crystals by a Grain-Coarsening Method," Trans. AIME (1957) 209, 882-888.

11. Lloyd, L. T. and Chiswik, H. H., "Deformation Mechanisms of AlphaUranium Single Crystals," ANL 5367, December 14, 1954.

12. Greninger, A. B., "Determination of Orientations of Metallic Crystals," Trans. AIME (1935) $117,61$.

13. Lloyd, L. T., "Recording Quartz Differential Dilatometer," ANL 5372 , February, 1959.

14. Wooster, W. A., "A Text-Book on Crystal Physics," Cambridge University Press, 1949, p. 21.

15. Souder, W. and Hidnert, P., "Measurements of the Thermal Expansions of Fused Silica," Scientific Papers of the Bureau of Standards, (1925) 21 . 
TABLE I

Alpha-Uranium Lattıce Parameter Data of Bridge, Schwartz and Vaughan(1)

\begin{tabular}{|c|c|c|c|c|c|c|c|c|}
\hline \multirow{2}{*}{$\begin{array}{l}\text { Temperature } \\
\left({ }^{\circ} \mathrm{K}\right)\end{array}$} & \multicolumn{2}{|c|}{$a_{0}-(\AA)$} & \multicolumn{2}{|c|}{$b_{0}-(\AA)$} & \multicolumn{2}{|c|}{$c_{0}-(\AA)$} & \multicolumn{2}{|c|}{ Unit Cell Volume $-\left(\AA^{3}\right)$} \\
\hline & Observed & $\mathrm{R}_{1} *$ & Observed & $R_{1}$ & Observed & $\mathrm{R}_{1}$ & $a_{0} b_{0} c_{0}$ & $\mathbf{R}_{1}$ \\
\hline 20 & 28416 & $-00051_{8}$ & 58657 & 000134 & 49306 & -000084 & 82183 & -01479 \\
\hline 63 & 28363 & $00025_{0}$ & 58662 & $00005_{2}$ & 49358 & -000165 & $82 \quad 123$ & $0 \quad 042_{4}$ \\
\hline 63 & 28394 & -000060 & 58666 & $00001_{2}$ & 49316 & $00025_{5}$ & 82149 & $0016_{4}$ \\
\hline 88 & 28378 & 000239 & 58664 & $00002_{3}$ & 49352 & 000142 & 82160 & 00826 \\
\hline 88 & 28413 & $-00011_{1}$ & 58679 & -000127 & 49389 & -000228 & 82344 & -01014 \\
\hline 123 & 28432 & $-00010_{3}$ & 58682 & $-00016_{0}$ & 49396 & 000040 & 82415 & -00626 \\
\hline 123 & 28388 & 000337 & 58662 & $00004_{0}$ & 49421 & $-00021_{0}$ & 82301 & $0051_{4}$ \\
\hline 173 & 28420 & $00030_{6}$ & 58671 & $-00004_{0}$ & 49429 & $00018_{4}$ & 82194 & 03197 \\
\hline 173 & 28434 & 000166 & 58693 & -000260 & 49456 & -000086 & 82536 & -00223 \\
\hline 188 & 28450 & 000094 & 58645 & 000225 & 49426 & $00035_{5}$ & 82466 & 00972 \\
\hline 300 & 28541 & -000116 & 58692 & $-00020_{3}$ & 49548 & 000199 & 82999 & -00465 \\
\hline 300 & 28551 & -000216 & 58682 & $-00010_{3}$ & 49570 & $-00002_{1}$ & 83051 & -00985 \\
\hline 300 & 28531 & -000016 & 58656 & 000157 & 49571 & $-00003_{1}$ & 82958 & -00055 \\
\hline 370 & 28605 & -000274 & 58673 & -000009 & 49636 & 000024 & 83306 & $-0 \quad 0898$ \\
\hline 373 & 28580 & $-00000_{3}$ & 58663 & 000090 & 49621 & 000206 & 83194 & 00339 \\
\hline 375 & 28612 & -000308 & 58669 & $00003_{0}$ & 49672 & -000283 & 83381 & $-0145_{3}$ \\
\hline 375 & 28592 & -000118 & 58659 & 000130 & 49685 & -000413 & 83334 & -00983 \\
\hline 448 & 28612 & 000217 & 58672 & -000048 & 49716 & $00008_{2}$ & 83468 & 00642 \\
\hline 473 & 28659 & -000020 & 58644 & $00020_{0}$ & 49769 & $-00015_{1}$ & 83646 & $-0007_{0}$ \\
\hline 548 & 28720 & 000026 & 58637 & 000113 & 49875 & $-00024_{5}$ & 83992 & $-0015_{0}$ \\
\hline 598 & 28759 & 000116 & 58651 & -000194 & 49901 & $00021_{4}$ & 84170 & $0048_{0}$ \\
\hline 673 & 28866 & $-00016_{3}$ & 58627 & -000318 & 49993 & 90050 0 & 84604 & 00016 \\
\hline 673 & 28821 & 000287 & 58563 & $00032_{2}$ & 50040 & 000039 & 84460 & 01456 \\
\hline 724 & 28900 & 000089 & 58558 & $00003_{6}$ & 50146 & -000089 & 84863 & $0025_{3}$ \\
\hline 748 & 28924 & $00014_{4}$ & $; 8539$ & $00004_{0}$ & 50176 & $00008_{2}$ & 84957 & $0070_{1}$ \\
\hline 794 & 29007 & -000090 & 58550 & $-00048_{0}$ & 50284 & $-00003_{1}$ & 85400 & -00964 \\
\hline 823 & 29052 & $-00014_{3}$ & 58456 & $00016_{2}$ & 50396 & -000497 & 85586 & -01006 \\
\hline 845 & 29055 & $00014_{0}$ & 58443 & 000045 & 50379 & 000195 & 85547 & $0080_{4}$ \\
\hline 885 & 29156 & $-00027_{4}$ & 58386 & $00011_{7}$ & 50533 & $-00034_{1}$ & 86022 & -01276 \\
\hline 913 & 29160 & 000124 & 58358 & و 00000 & 50539 & $00034_{8}$ & 86003 & 00855 \\
\hline $\begin{array}{c}\text { Standard } \\
\text { deviation } \\
(\sigma)\end{array}$ & \multicolumn{2}{|c|}{000212} & \multicolumn{2}{|c|}{000162} & \multicolumn{2}{|c|}{$00024_{0}$} & \multicolumn{2}{|c|}{00973} \\
\hline
\end{tabular}

$*_{R_{1}}=D_{1} f f e r e n c e$ between value calculated from least mean square fitted equation and observed value 
TABLE II

Alpha-Uranium Lattice Parameter Data of Chiotti, Klepfer and White(2)

\begin{tabular}{|c|c|c|c|c|c|c|c|c|}
\hline \multirow{2}{*}{$\begin{array}{c}\text { Temperature } \\
{ }^{\circ} \mathrm{C}\end{array}$} & \multicolumn{2}{|c|}{$a_{0}-(\AA)$} & \multicolumn{2}{|c|}{$b_{0}-(\AA)$} & \multicolumn{2}{|c|}{$c_{0}-(\AA)$} & \multicolumn{2}{|c|}{$\begin{array}{c}\text { Unit Cell Volume - } \\
\left(\AA^{3}\right)\end{array}$} \\
\hline & Observed & $\mathrm{Ri}{ }^{*}$ & Observed & $\mathrm{Ri}$ & Observed & Ri & Observed & $\mathrm{Ri}$ \\
\hline 20 & 2.8526 & $0.0006_{5}$ & 5.8682 & $-0.0034_{4}$ & 4.9489 & $0.0048_{2}$ & 82.843 & $0.051_{2}$ \\
\hline 20 & 2.8537 & -0.00045 & 5.8619 & 0.00286 & 4.9565 & -0.00278 & 82.912 & $-0.018_{8}$ \\
\hline 27 & 2.8543 & -0.00066 & 5.8641 & $0.0006_{4}$ & 4.9575 & -0.00322 & 82.978 & -0.0633 \\
\hline 101 & 2.8578 & $0.0004_{4}$ & 5.8636 & $0.0011_{0}$ & 4.9616 & $-0.0006_{8}$ & 83.142 & $0.016_{2}$ \\
\hline 105 & 2.8582 & $0.0003_{1}$ & 5.8660 & -0.00130 & 4.9578 & $0.0035_{2}$ & 83.123 & 0.0497 \\
\hline 200 & 2.8662 & -0.00055 & 5.8649 & -0.00049 & 4.9705 & $0.0013_{3}$ & 83.554 & -0.0012 \\
\hline 204 & 2.8657 & 0.00028 & 5.8634 & 0.00098 & 4.9741 & $-0.0017_{8}$ & 83.578 & -0.0078 \\
\hline 212 & 2.8663 & $0.0003_{4}$ & 5.8646 & -0.00028 & 4.9751 & -0.00179 & 83.630 & -0.0247 \\
\hline 304 & 2.8751 & $-0.0001_{3}$ & 5.8636 & $-0.0008_{0}$ & 4.9844 & 0.00137 & 84,029 & $0.007_{8}$ \\
\hline 306 & 2.8756 & $-0.0004_{4}$ & 5.8620 & $0.0007_{5}$ & 4.9881 & $-0.0020_{4}$ & 84.083 & $-0.036_{3}$ \\
\hline 400 & 2.8849 & $0.0000_{8}$ & 5.8594 & -0.00030 & 4.9985 & 0.00238 & 84.494 & 0.0380 \\
\hline 400 & 2.8845 & $0.0004_{8}$ & 5.8602 & $-0.0011_{0}$ & 4.9996 & $0.0012_{8}$ & 84.512 & $0.020_{0}$ \\
\hline 403 & 2.8859 & $-0.0005 q$ & 5.8575 & 0.00144 & 5.0033 & $-0.0019_{1}$ & 84.576 & $-0.028_{0}$ \\
\hline 505 & 2.8971 & 0.00036 & 5.8516 & -0.00010 & 5.0203 & $-0.0004_{l}$ & 85.107 & $0.002_{8}$ \\
\hline 602 & 2.9113 & $-0.0008_{5}$ & 5.8402 & -0.00006 & 5.0394 & 0.00036 & 85.683 & $-0.021_{0}$ \\
\hline 603 & 2.9106 & $-0.0000_{3}$ & 5.8406 & -0.00060 & 5.0407 & $-0.0007_{3}$ & 85.690 & -0.0222 \\
\hline 603 & 2.9098 & 0.00077 & 5.8393 & $0.0007_{0}$ & 5.0397 & 0.00027 & 85.630 & 0.0378 \\
\hline $\begin{array}{c}\text { Standard } \\
\text { deviation } \\
(\sigma)\end{array}$ & \multicolumn{2}{|c|}{0.00055} & \multicolumn{2}{|c|}{$0.0012_{5}$} & \multicolumn{2}{|c|}{0.00226} & \multicolumn{2}{|c|}{0.0329} \\
\hline
\end{tabular}

$*_{\mathrm{Ri}}=$ Difference between value calculated from least mean square fitted equation and observed value. 
TABLE III

Thermal Expansion of Crystal $T_{D}$ in the [100] Direction*

\begin{tabular}{|r|r|c|c|c|c|}
\hline \multicolumn{1}{r|}{$t$} & $\Delta_{\mathrm{E}}$ & $\mathrm{L}_{\mathrm{E}}$ & $\mathrm{K}_{\mathrm{t}}$ & $\mathrm{L}_{\mathrm{t}}$ & $\frac{\mathrm{L}_{\mathrm{t}^{\circ} \mathrm{C}}-\mathrm{L}_{25^{\circ} \mathrm{C}} \times 10^{4}}{\mathrm{~L}_{25^{\circ}} \mathrm{C}}$ \\
\hline \hline 24 & 0.00 & 0.129920 & 1.000000 & 0.129920 & - \\
25 & 0.05 & 0.129926 & 1.000001 & 0.129927 & 0.00 \\
50 & 0.50 & 0.129985 & 1.000015 & 0.129987 & 4.66 \\
75 & 1.05 & 0.130057 & 1.000030 & 0.130061 & 10.32 \\
100 & 1.60 & 0.130128 & 1.000044 & 0.130134 & 15.98 \\
125 & 2.25 & 0.130213 & 1.000058 & 0.130221 & 22.65 \\
150 & 2.90 & 0.130298 & 1.000073 & 0.130307 & 29.31 \\
175 & 3.70 & 0.130402 & 1.000087 & 0.130413 & 37.47 \\
200 & 4.40 & 0.130493 & 1.000101 & 0.130506 & 44.63 \\
225 & 5.20 & 0.130598 & 1.000115 & 0.130612 & 52.80 \\
250 & 5.90 & 0.130689 & 1.000129 & 0.130706 & 59.96 \\
275 & 6.60 & 0.130780 & 1.000142 & 0.130798 & 67.11 \\
300 & 7.40 & 0.130884 & 1.000155 & 0.130904 & 75.27 \\
325 & 8.30 & 0.131001 & 1.000169 & 0.131024 & 84.43 \\
350 & 9.20 & 0.131119 & 1.000182 & 0.131143 & 93.59 \\
375 & 10.15 & 0.131242 & 1.000195 & 0.131268 & 103.25 \\
400 & 11.15 & 0.131373 & 1.000208 & 0.131400 & 113.41 \\
425 & 12.15 & 0.131503 & 1.000220 & 0.131532 & 123.57 \\
450 & 13.20 & 0.131640 & 1.000233 & 0.131671 & 134.23 \\
475 & 14.20 & 0.131770 & 1.000245 & 0.131802 & 144.38 \\
500 & 15.35 & 0.131920 & 1.000257 & 0.131954 & 156.04 \\
525 & 16.55 & 0.132076 & 1.000269 & 0.132112 & 168.20 \\
550 & 17.65 & 0.132220 & 1.000281 & 0.132257 & 179.36 \\
575 & 18.75 & 0.132363 & 1.000293 & 0.132402 & 190.52 \\
600 & 20.50 & 0.132591 & 1.000307 & 0.132632 & 208.18 \\
625 & 21.80 & 0.132760 & 1.000316 & 0.132802 & 221.35 \\
650 & 23.20 & 0.132943 & 1.000328 & 0.132986 & 235.51 \\
\hline & & & & & \\
\hline
\end{tabular}

$*_{\mathrm{t}}=$ temperature $-{ }^{\circ} \mathrm{C}$.

$\Delta \mathrm{L}_{\mathrm{E}}=$ indicated dilatation in units of $1 / 3$ " as read from dilatometer curve.

$L_{E}=$ indicated length of crystal = measured length of crystal at reference temperature $\left(24^{\circ} \mathrm{C}\right)$ plus magnification factor for $\mathrm{H}^{\prime}$ scale of dilatometer $\left(1,303 \times 10^{-4}\right)$ times $\Delta L_{E}$.

$=0.12992+1.303 \times 10^{-4} \cdot \Delta \mathrm{L}_{\mathrm{E}}$.

$\mathrm{K}_{\mathrm{t}}=$ correction factor due to dilatation of quartz components in the dilatometer.

$=$ length of a piece of quartz at $t$ whose length at $24^{\circ} \mathrm{C}$ equals 1.000000 .

$\mathrm{L}_{\mathrm{t}}=\mathrm{K}_{\mathrm{t}} \cdot \mathrm{L}_{\mathrm{E}}$

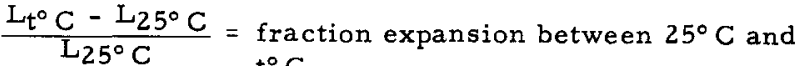
$\mathrm{t}^{\circ} \mathrm{C}$. 
TABLE IV

Alpha-Uranium Thermal Expansion in the [100] Direction $-\left(\frac{L_{t^{\circ} \mathrm{C}}-L_{25^{\circ}} \mathrm{C}}{\mathrm{L}_{25^{\circ}} \mathrm{C}}\right)$

\begin{tabular}{|c|c|c|c|c|c|c|}
\hline \multirow{2}{*}{$\begin{array}{c}\text { Temperature } \\
\left({ }^{\circ} \mathrm{C}\right)\end{array}$} & \multicolumn{4}{|c|}{ Data from Single Crystals $\times 10^{4}$} & \multicolumn{2}{|c|}{ Data from Lattıce Parameter $\times 10^{4}$} \\
\hline & $\begin{array}{c}\text { Crystal } \mathrm{T}_{\mathrm{D}} \\
\mathrm{L}_{24^{\circ} \mathrm{C}}=0.12992^{\prime \prime}\end{array}$ & $\begin{array}{c}\text { Crystal } \mathrm{T}_{\mathrm{F}} \\
\mathrm{L}_{24^{\circ} \mathrm{C}=014665^{\prime \prime}}\end{array}$ & Average & $\mathrm{R}_{1} *$ & $\begin{array}{c}\text { Bridge, Schwartz } \\
\text { and Vaughan }\end{array}$ & $\begin{array}{c}\text { Chrottı, Klepfer } \\
\text { and White }\end{array}$ \\
\hline 25 & 000 & 000 & 000 & -1349 & 000 & 000 \\
\hline 50 & 466 & 503 & 484 & $-0 \quad 050$ & 586 & 511 \\
\hline 75 & 1032 & 1096 & 1064 & 0494 & 1189 & 1052 \\
\hline 100 & 1598 & 1776 & 1687 & 0795 & 1812 & 1627 \\
\hline 125 & 2264 & 2457 & $2: 60$ & $080_{5}$ & 2456 & 2234 \\
\hline 150 & 2931 & 3182 & 3056 & 0812 & 3120 & 2873 \\
\hline 175 & 3747 & 3952 & 3850 & $00_{4}$ & 3808 & 3543 \\
\hline 200 & 4463 & 4765 & 4614 & -0147 & 4520 & 4246 \\
\hline 225 & 5280 & 5579 & 5430 & $-062_{3}$ & 5259 & 49.81 \\
\hline 250 & 5996 & 6392 & 6194 & $-034_{0}$ & 6024 & 5747 \\
\hline 275 & 6711 & 7250 & 6980 & $-001_{3}$ & 6820 & 6549 \\
\hline 300 & 7527 & 8108 & 7818 & 0088 & 7645 & 7376 \\
\hline 325 & 8443 & 8965 & 8704 & $\begin{array}{lll}-0 & 02\end{array}$ & 8501 & 8239 \\
\hline 350 & 9359 & 9867 & 9613 & $\begin{array}{lll}-0 & 073\end{array}$ & 9391 & 9134 \\
\hline 375 & 10325 & 10858 & 10592 & -0510 & 10315 & 10060 \\
\hline 400 & 11341 & 11804 & 11572 & $-066_{2}$ & 11276 & 11019 \\
\hline 425 & 12357 & 12794 & 12576 & $-071_{5}$ & 12272 & 12009 \\
\hline 450 & 13423 & 13695 & 13559 & -0243 & 13308 & 13033 \\
\hline 475 & 14438 & 14774 & 14606 & $\begin{array}{lll}-0 & 06_{8}\end{array}$ & 14384 & 14087 \\
\hline 500 & 15604 & 15808 & 15706 & $\begin{array}{lll}-0 & 074\end{array}$ & 15501 & $151 \quad 74$ \\
\hline 525 & 16820 & 16798 & 16809 & 0250 & 16612 & 16292 \\
\hline 550 & 17936 & 17877 & 17906 & 1000 & 17866 & 17443 \\
\hline 575 & 19052 & 18955 & 19004 & 2128 & 19116 & 18626 \\
\hline 600 & 20817 & 20078 & 20448 & 0167 & 20412 & 198.40 \\
\hline 625 & 22135 & 21378 & 21756 & $\begin{array}{lll}-0 & 04_{3}\end{array}$ & 21758 & 21087 \\
\hline 650 & 23551 & 22945 & 23248 & -1675 & 23054 & 22366 \\
\hline
\end{tabular}

$*_{R_{1}}=D_{1}$ fference between value calculated from least mean square fitted equation and average value Standard deviation $\sigma=0638 \times 10^{-4}$ 
Table V

Alpha-Uranium Thermal Expansion in the [010] Direction $-\left(\frac{L_{t}{ }^{\circ} \mathrm{C}-L_{25^{\circ}} \mathrm{C}}{L_{25^{\circ}} \mathrm{C}}\right)$

\begin{tabular}{|c|c|c|c|c|c|c|c|}
\hline \multirow{2}{*}{$\begin{array}{l}\text { Temperature } \\
\left({ }^{\circ} \mathrm{C}\right)\end{array}$} & \multicolumn{5}{|c|}{ Data from Single Crystals $\times 10^{4}$} & \multicolumn{2}{|c|}{$\begin{array}{l}\text { Data from Lattice } \\
\text { Parameter } \times 10^{4}\end{array}$} \\
\hline & $\begin{array}{c}\text { Crystal } \mathrm{T}_{\mathrm{A}} \\
\mathrm{L}_{23^{\circ} \mathrm{C}}=03059_{1} "\end{array}$ & $\begin{array}{c}\text { Crystal } \mathrm{T}_{\mathrm{B}} \\
\mathrm{L}_{24^{\circ} \mathrm{C}}=02413^{\prime \prime}\end{array}$ & $\begin{array}{c}\text { Crystal } \mathrm{T}_{\mathrm{C}} \\
\mathrm{L}_{24^{\circ} \mathrm{C}}=014567^{11}\end{array}$ & Average & $\mathrm{R}_{1} *$ & $\begin{array}{c}\text { Bridge, } \\
\text { Schwartz } \\
\text { and Vaughan }\end{array}$ & $\begin{array}{l}\text { Chiott1, } \\
\text { Klepfer } \\
\text { and White }\end{array}$ \\
\hline 25 & 000 & 000 & 000 & 000 & 0109 & 000 & 000 \\
\hline 50 & -006 & 014 & 015 & 008 & 0132 & 009 & -006 \\
\hline 125 & -048 & -036 & -031 & -038 & 0009 & -009 & -011 \\
\hline 150 & -098 & -049 & -106 & -084 & -0058 & -035 & -018 \\
\hline 175 & -148 & -088 & -182 & -139 & -0219 & -075 & -033 \\
\hline 200 & -240 & -155 & -302 & -232 & -0192 & -129 & -058 \\
\hline 225 & -376 & -236 & -467 & -360 & $\begin{array}{lll}-0 & 034\end{array}$ & -200 & -095 \\
\hline 250 & -511 & -371 & -588 & -490 & $\begin{array}{lll}-0 & 06\end{array}$ & -289 & -149 \\
\hline 400 & -1732 & -1599 & $-21 \quad 19$ & -1817 & $004_{9}$ & -1301 & -963 \\
\hline 425 & -2038 & -1910 & -2509 & -2152 & 0247 & -1566 & -1207 \\
\hline 450 & -2346 & -2234 & -2944 & -2508 & 0336 & -1862 & -1490 \\
\hline 475 & -2674 & -2586 & -3334 & -2865 & $012_{1}$ & -2191 & -1813 \\
\hline 500 & $\begin{array}{lll}-30 & 03\end{array}$ & -2965 & -3814 & -3261 & $\begin{array}{lll}-0 & 032\end{array}$ & -2556 & $\begin{array}{ll}-21 & 81\end{array}$ \\
\hline 525 & -3374 & -3438 & -4205 & -3672 & $\begin{array}{lll}-0 & 36 \\
4\end{array}$ & -2958 & -2595 \\
\hline 550 & -3831 & -3884 & -4730 & $-41 \quad 48$ & $-040_{4}$ & -3398 & -3060 \\
\hline 575 & -4330 & -4439 & -5255 & -4675 & $-030_{1}$ & -3879 & -3576 \\
\hline 600 & -4915 & -4993 & -5825 & -5244 & -0136 & $\begin{array}{lll}-44 & 02\end{array}$ & -4148 \\
\hline 625 & -5458 & -5575 & -6529 & -5854 & $00_{3}$ & -4968 & -4779 \\
\hline 650 & -6043 & -6211 & -7323 & -6526 & 0449 & -5580 & -5470 \\
\hline
\end{tabular}

$* R_{I}=D_{1} f f e r e n c e$ between value calculated from least mean square fitted equation and average value Standard deviation $=0191 \times 10^{-4}$ 
TABLE VI

Alpha-Uranium Thermal Expansion in the [001] Direction $-\left(\frac{L_{t^{\circ}} \mathrm{C}-L_{25^{\circ} \mathrm{C}}}{L_{25^{\circ} \mathrm{C}}}\right)$

\begin{tabular}{|c|c|c|c|c|c|c|}
\hline \multirow{2}{*}{$\begin{array}{c}\text { Temperature } \\
\left({ }^{\circ} \mathrm{C}\right)\end{array}$} & \multicolumn{4}{|c|}{ Data from Single Crystals $\times 10^{4}$} & \multicolumn{2}{|c|}{ Data from Lattice Parameters $\times 10^{4}$} \\
\hline & $\begin{array}{c}\text { Crystal } \mathrm{T}_{\mathrm{C}} \\
\mathrm{L}_{24^{\circ} \mathrm{C}}=01681_{1} 1\end{array}$ & $\begin{array}{c}\text { Crystal } \mathrm{T}_{\mathrm{D}} \\
\mathrm{L}_{25^{\circ} \mathrm{C}=011555^{\prime \prime}}\end{array}$ & Average & $\mathrm{R}_{1} *$ & $\begin{array}{l}\text { Bridge, Schwartz } \\
\text { and Vaughan }\end{array}$ & $\begin{array}{l}\text { Chiott1, Klepfer } \\
\text { and White }\end{array}$ \\
\hline 25 & 000 & 000 & 000 & $031_{5}$ & 000 & 000 \\
\hline 50 & 596 & 522 & 559 & -0026 & 497 & 423 \\
\hline 75 & 1114 & 1044 & 1079 & 0299 & 1004 & 874 \\
\hline 100 & 1788 & 1566 & 1677 & $012_{8}$ & 1526 & 1355 \\
\hline 125 & 2422 & 2257 & 2340 & $-04 l_{1}$ & 2063 & 1866 \\
\hline 150 & 3095 & 2892 & 2994 & $-057_{5}$ & 2618 & 24.07 \\
\hline 175 & 3768 & 3526 & 3647 & -0450 & 3193 & 2973 \\
\hline 200 & 4441 & 4273 & 4357 & $\begin{array}{ll}-0 & 597\end{array}$ & 3791 & 3576 \\
\hline 225 & 5075 & 4964 & 5020 & 0028 & 4413 & 4206 \\
\hline 250 & 5864 & 5654 & 5759 & 0178 & 5062 & 4865 \\
\hline 275 & 6614 & 6401 & 6508 & $054_{0}$ & 5740 & 5554 \\
\hline 300 & 7364 & 7260 & 7312 & $064_{4}$ & 6449 & 6272 \\
\hline 325 & 8191 & 8232 & 8212 & 0105 & 7191 & 7019 \\
\hline 350 & 8997 & 9091 & 9044 & 0545 & 7970 & 7797 \\
\hline 375 & 9484 & 10119 & 10002 & $051_{9}$ & 8786 & 8604 \\
\hline 400 & 10827 & 11091 & 10959 & -0130 & 9641 & 9440 \\
\hline 425 & 11770 & 12118 & 11944 & $-026_{4}$ & 10540 & 10306 \\
\hline 450 & 12713 & 13090 & 12902 & $02 \mathrm{O}_{3}$ & 11482 & 11203 \\
\hline 475 & 13733 & 14174 & 13954 & $0 \quad 045$ & 12472 & 12127 \\
\hline 500 & 14831 & 15258 & 15044 & $-017_{0}$ & 13510 & 13083 \\
\hline 525 & 15928 & 16342 & 16135 & $-005_{3}$ & 14600 & 14067 \\
\hline 550 & 17181 & 17482 & 17332 & -0656 & 15742 & 15082 \\
\hline 575 & 18395 & 18509 & 18452 & $-016_{3}$ & 169.41 & 16126 \\
\hline 600 & 19647 & 19649 & 19648 & $\begin{array}{lll}-0 & 08_{5}\end{array}$ & 18197 & 17199 \\
\hline 625 & 20938 & 20845 & 20892 & $\begin{array}{llll}-0 & 1 & 3 \\
7\end{array}$ & 19512 & 18303 \\
\hline 650 & 22190 & 21985 & 22088 & 0635 & 20891 & 19435 \\
\hline
\end{tabular}

* $R_{1}=D_{1} f$ erence between value calculated from least mean square fitted equation and average value Standard deviation $=0358 \times 10^{-4}$ 
TABLE VII

Volumetric Thermal Expansion of Alpha-Uranium $-\left(\frac{V_{t^{\circ} \mathrm{C}}-\mathrm{V}_{25^{\circ}} \mathrm{C}}{\mathrm{V}_{25^{\circ} \mathrm{C}}}\right)$

\begin{tabular}{|c|c|c|c|c|}
\hline \multirow{3}{*}{$\begin{array}{l}\text { Temperature } \\
\left({ }^{\circ} \mathrm{C}\right)\end{array}$} & \multicolumn{4}{|c|}{ Calculated Volume Expansion $\times 10^{4}$} \\
\hline & \multicolumn{2}{|c|}{ From Single Crystal Data } & \multicolumn{2}{|c|}{ From Lattice Parameter Data } \\
\hline & 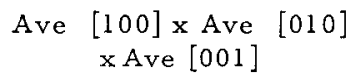 & $\mathrm{R}_{1} *$ & $\begin{array}{l}\text { Bridge, Schwartz } \\
\text { and Vaughan(1) }\end{array}$ & $\begin{array}{l}\text { Chiott1, Klepfer } \\
\text { and White }(2)\end{array}$ \\
\hline 25 & 000 & $-090_{8}$ & 000 & 000 \\
\hline 50 & 1052 & 0061 & 1109 & 921 \\
\hline 75 & 2162 & 0780 & 2244 & 1910 \\
\hline 100 & 3378 & 0790 & 3408 & 2964 \\
\hline 125 & 4668 & 0393 & 4600 & 4080 \\
\hline 150 & 5975 & 0168 & 5823 & 5254 \\
\hline 175 & 7370 & -0607 & 7077 & 6484 \\
\hline 200 & 8757 & -0946 & 8365 & 7767 \\
\hline 225 & 10113 & -0633 & 9686 & 9100 \\
\hline 250 & 11493 & -0223 & 11044 & 10480 \\
\hline 275 & 12878 & 0485 & 12438 & 11876 \\
\hline 300 & 14315 & $102_{0}$ & 13872 & 13368 \\
\hline 325 & 15923 & 0194 & 15344 & 14871 \\
\hline 350 & 17447 & 0547 & 16859 & 16409 \\
\hline 375 & 19136 & -0398 & 18416 & 17979 \\
\hline 400 & 20801 & -0742 & 20017 & 19578 \\
\hline 425 & 22464 & -0730 & 21663 & 21204 \\
\hline 450 & 24061 & 0306 & 23357 & 22852 \\
\hline 475 & 25816 & 0098 & 25098 & 24521 \\
\hline 500 & 27626 & -0288 & 26889 & 26208 \\
\hline 525 & 29421 & -0187 & 28730 & 27909 \\
\hline 550 & 31252 & $\begin{array}{lll}-0 & 0 & 8\end{array}$ & 30624 & 29633 \\
\hline 575 & 32954 & 1668 & 32571 & 31343 \\
\hline 600 & $350 \quad 40$ & $\begin{array}{lll}-0 & 06_{4}\end{array}$ & 34573 & 33070 \\
\hline 625 & 36996 & -0135 & 36631 & 34798 \\
\hline 650 & 39024 & -0568 & 38748 & 36528 \\
\hline
\end{tabular}

$* R_{1}-D_{1} f f e r e n c e$ between value calculated from least mean square fitted equation and observed value Standard deviation $=0628 \times 10^{-4}$

TABLE VIII

Testing Directions and Initial Lengths of Randomly Oriented Crystals

\begin{tabular}{|c|c|c|c|c|c|}
\hline \multirow{2}{*}{$\begin{array}{c}\text { Crystal } \\
\text { Identification }\end{array}$} & \multicolumn{2}{|c|}{$\begin{array}{c}\text { Location of Testing } \\
\text { Direction with Respect } \\
\text { to Principal Directions } \\
\text { (degrees) }\end{array}$} & \multicolumn{2}{|c|}{\begin{tabular}{c} 
Initial Length \\
\cline { 3 - 4 }
\end{tabular}} & \multicolumn{2}{|c|}{$\begin{array}{c}\text { Average of } \\
\text { Measurements } \\
\text { (1nches) }\end{array}$} & $\begin{array}{c}\text { Measurement } \\
\text { Temperature } \\
(100]\end{array}$ & {$[010]$} & {$[001]$} & & \\
\cline { 2 - 6 } & 86 & 135 & 77 & 01139 & 21 \\
$219-2$ & 83 & 85 & 815 & 00939 & 21 \\
$235-\mathrm{B}$ & 865 & 13 & 775 & 01484 & 21 \\
$240-\mathrm{A}$ & 835 & 105 & 795 & 01415 & 21 \\
$240-\mathrm{B}$ & 83 & 13 & 79 & 01476 & 21 \\
$240-\mathrm{C}$ & 84 & 11 & 805 & 03749 & 24 \\
$\mathrm{~T}_{\mathrm{G}}$ & & & & & \\
\hline
\end{tabular}


TABLE IX

Thermal Expansion of Crystal 219-2

\begin{tabular}{|c|c|c|c|c|}
\hline \multirow{3}{*}{$\begin{array}{l}\text { Temperature } \\
\left(t^{\circ} \mathrm{C}\right)\end{array}$} & \multicolumn{4}{|c|}{ Thermal Expansion $\times 10^{4}-\left(\frac{\mathrm{L}_{\mathrm{t}^{\circ} \mathrm{C}}-\mathrm{L}_{2} 5^{\circ} \mathrm{C}}{\mathrm{L}_{25^{\circ} \mathrm{C}}}\right)$} \\
\hline & \multirow{2}{*}{$\begin{array}{c}\text { From Dilatation } \\
\text { Curve }\end{array}$} & \multicolumn{3}{|c|}{ Calculated from Principal Direction Expansions } \\
\hline & & $\begin{array}{l}\text { Single } \\
\text { Crystals }\end{array}$ & $\begin{array}{l}\text { Bridge, Schwartz } \\
\text { and Vaughan }(1)\end{array}$ & $\begin{array}{l}\text { Chiotti, Klepfer } \\
\text { and White }(2)\end{array}$ \\
\hline 25 & 0.00 & 0.00 & 0.00 & 0.00 \\
\hline 50 & 0.72 & 0.48 & 0.36 & 0.18 \\
\hline 75 & 1.44 & 0.76 & 0.68 & 0.42 \\
\hline 100 & 1.58 & 0.90 & 0.93 & 0.69 \\
\hline 125 & 1.73 & 0.91 & 1.08 & 0.95 \\
\hline 150 & 1.30 & 0.77 & 1.14 & 1.19 \\
\hline 175 & 0.87 & 0.47 & 1.09 & 1.37 \\
\hline 200 & 0.43 & 0.00 & 0.92 & 1.47 \\
\hline 225 & -0.57 & -0.65 & 0.60 & 1.47 \\
\hline 250 & -1.58 & -1.48 & 0.12 & 1.33 \\
\hline 275 & -2.59 & -2.52 & -0.53 & 1.03 \\
\hline 300 & -4.17 & -3.76 & -1.37 & 0.54 \\
\hline 325 & -5.76 & -5.23 & -2.40 & -0.15 \\
\hline 350 & -7.34 & -6.93 & -3.66 & -1.09 \\
\hline 375 & -9.50 & -8.86 & -5.14 & -2.30 \\
\hline 400 & -11.09 & -11.05 & -6.87 & -3.79 \\
\hline 425 & -13.82 & -13.50 & -8.87 & -5.61 \\
\hline 450 & -15.99 & -16.22 & -11.15 & -7.78 \\
\hline 475 & -19.30 & -19.22 & -13.70 & -10.32 \\
\hline 500 & -22.61 & -22.51 & -16.58 & -13.26 \\
\hline 525 & -27.06 & -26.10 & -19.77 & -16.62 \\
\hline 550 & -31.52 & -30.01 & -23.29 & -20.45 \\
\hline 575 & -36.56 & -34.24 & -27.17 & -24.74 \\
\hline 600 & -41.02 & -38.80 & -31.42 & -29.55 \\
\hline 625 & -46.62 & -43.70 & -36.04 & -34.90 \\
\hline 650 & -49.94 & -48.96 & -41.06 & -40.80 \\
\hline
\end{tabular}


TABLE $X$

Thermal Expansion of Crystal 235-B

\begin{tabular}{|c|c|c|c|c|}
\hline \multirow{3}{*}{$\begin{array}{l}\text { Temperature } \\
\qquad\left(t^{\circ} \mathrm{C}\right)\end{array}$} & \multicolumn{4}{|c|}{ Thermal Expansion $\times 10^{4}-\left(\frac{\mathrm{L}_{\mathrm{t}^{\circ} \mathrm{C}}-\mathrm{L}_{25^{\circ} \mathrm{C}}}{\mathrm{L}_{25^{\circ} \mathrm{C}}}\right)$} \\
\hline & \multirow{2}{*}{$\begin{array}{c}\text { From Dilatation } \\
\text { Curve }\end{array}$} & \multicolumn{3}{|c|}{ Calculated from Principal Direction Expansions } \\
\hline & & $\begin{array}{l}\text { Single } \\
\text { Crystals }\end{array}$ & $\begin{array}{l}\text { Bridge, Schwartz } \\
\text { and Vaughan (1) }\end{array}$ & $\begin{array}{l}\text { Chiotti, Klepfer } \\
\text { and White }(2)\end{array}$ \\
\hline 25 & 0.00 & 0.00 & 0.00 & 0.00 \\
\hline 50 & 0.15 & 0.31 & 0.20 & 0.04 \\
\hline 75 & -0.40 & 0.39 & 0.34 & 0.12 \\
\hline 100 & -0.53 & 0.34 & 0.41 & 0.22 \\
\hline 125 & -1.08 & 0.13 & 0.37 & 0.31 \\
\hline 150 & -1.63 & -0.25 & 0.24 & 0.36 \\
\hline 175 & -1.91 & -0.79 & -0.02 & 0.34 \\
\hline 200 & -3.16 & -1.52 & -0.42 & 0.23 \\
\hline 225 & -3.71 & -2.45 & -0.98 & 0.00 \\
\hline 250 & -4.96 & -3.58 & -1.70 & -0.38 \\
\hline 275 & -6.22 & -4.93 & -2.62 & -0.94 \\
\hline 300 & -7.47 & -6.51 & -3.74 & -1.70 \\
\hline 325 & -8.73 & -8.33 & -5.08 & -2.69 \\
\hline 350 & -10.68 & -10.39 & -6.66 & -3.94 \\
\hline 375 & -12.63 & -12.71 & -8.49 & -5.47 \\
\hline 400 & -14.58 & -15.31 & -10.58 & -7.32 \\
\hline 425 & -17.93 & -18.19 & -12.98 & -9.52 \\
\hline 450 & -20.58 & -21.36 & -15.66 & -12.09 \\
\hline 475 & -23.93 & -24.82 & -18.66 & -15.04 \\
\hline 500 & -27.28 & -28.61 & -22.00 & -18.43 \\
\hline 525 & -31.32 & -32.72 & -25.69 & -22.26 \\
\hline 550 & -36.06 & -37.16 & -29.74 & -26.58 \\
\hline 575 & -42.19 & -41.95 & -34.18 & -31.40 \\
\hline 600 & -46.93 & -47.10 & -39.02 & -36.76 \\
\hline 625 & $-52.37^{-}$ & -52.61 & -44.26 & -42.68 \\
\hline 650 & -59.20 & -58.50 & -49.95 & -49.19 \\
\hline
\end{tabular}


TABLE XI

Thermal Expansion of Crystal 240-A

\begin{tabular}{|c|c|c|c|c|}
\hline \multirow{3}{*}{$\begin{array}{l}\text { Temperature } \\
\left(\mathrm{t}^{\circ} \mathrm{C}\right)\end{array}$} & \multicolumn{4}{|c|}{ Thermal Expansion $\times 10^{4}-\left(\frac{L_{t^{\circ}} \mathrm{C}-L_{25^{\circ} \mathrm{C}}}{L_{25^{\circ} \mathrm{C}}}\right)$} \\
\hline & \multirow{2}{*}{$\begin{array}{l}\text { From Dilatation } \\
\text { Curve }\end{array}$} & \multicolumn{3}{|c|}{ Calculated from Principal Direction Expansions } \\
\hline & & $\begin{array}{c}\text { Single } \\
\text { Crystals }\end{array}$ & $\begin{array}{l}\text { Bridge, Schwartz } \\
\text { and Vaughan(1) }\end{array}$ & $\begin{array}{c}\text { Chiotti, Klepfer } \\
\text { and White(2) }\end{array}$ \\
\hline 25 & 0.00 & 0.00 & 0.00 & 0.00 \\
\hline 50 & 0.59 & 0.46 & 0.34 & 0.16 \\
\hline 75 & 1.17 & 0.70 & 0.63 & 0.37 \\
\hline 100 & 1.76 & 0.82 & 0.85 & 0.62 \\
\hline 125 & 1.90 & 0.79 & 0.97 & 0.85 \\
\hline 150 & 1.82 & 0.62 & 1.01 & 1.06 \\
\hline 175 & 1.74 & 0.28 & 0.92 & 1.21 \\
\hline 200 & 1.44 & -0.22 & 0.72 & 1.28 \\
\hline 225 & 0.70 & -0.91 & 0.36 & 1.25 \\
\hline 250 & -0.04 & -1.79 & -0.15 & 1.08 \\
\hline 275 & -0.78 & -2.87 & -0.84 & 0.74 \\
\hline 300 & -1.96 & -4.16 & -1.72 & 0.21 \\
\hline 325 & -3.15 & -5.68 & -2.80 & -0.52 \\
\hline 350 & -4.34 & -7.43 & -4.10 & -1.51 \\
\hline 375 & -5.08 & -9.42 & -5.63 & -2.76 \\
\hline 400 & -6.71 & -11.66 & -7.41 & -4.31 \\
\hline 425 & -8.34 & -14.17 & -9.47 & -6.18 \\
\hline 450 & -9.97 & -16.95 & -11.80 & -8.41 \\
\hline 475 & -12.05 & -20.02 & -14.42 & -11.01 \\
\hline 500 & -14.56 & -23.38 & -17.36 & -14.01 \\
\hline 525 & -17.07 & -27.05 & -20.62 & -17.44 \\
\hline 550 & -20.03 & -31.03 & -24.22 & -21.34 \\
\hline 575 & -23.42 & -35.33 & -28.18 & -25.70 \\
\hline 600 & -27.70 & -39.98 & -32.51 & -30.58 \\
\hline 625 & -31.98 & -44.97 & -37.21 & -36.01 \\
\hline 650 & -35.81 & -50.31 & -42.33 & -41.99 \\
\hline
\end{tabular}


TABLE XII

Thermal Expansion of Crystal 240-B

\begin{tabular}{|c|c|c|c|c|}
\hline \multirow{3}{*}{$\begin{array}{l}\text { Temperature } \\
\qquad\left(t^{\circ} \mathrm{C}\right)\end{array}$} & \multicolumn{4}{|c|}{ Thermal Expansion $\times 10^{4}-\left(\frac{L_{t^{\circ}} \mathrm{C}-L_{25^{\circ} \mathrm{C}}}{L_{25^{\circ} \mathrm{C}}}\right)$} \\
\hline & \multirow{2}{*}{$\begin{array}{l}\text { From Dilatation } \\
\text { Curve }\end{array}$} & \multicolumn{3}{|c|}{ Calculated from Princ1pal Direction Expansions } \\
\hline & & $\begin{array}{l}\text { Single } \\
\text { Crystals }\end{array}$ & $\begin{array}{l}\text { Bridge, Schwartz } \\
\text { and Vaughan }(1)\end{array}$ & $\begin{array}{l}\text { Chiott1, Klepfer } \\
\text { and White }(2)\end{array}$ \\
\hline 25 & 000 & 000 & 000 & 000 \\
\hline 50 & 107 & 037 & 026 & 008 \\
\hline 75 & 214 & 052 & 048 & 022 \\
\hline 100 & 228 & 053 & 059 & 038 \\
\hline 125 & 242 & 040 & 061 & 053 \\
\hline 150 & 165 & 011 & 055 & 064 \\
\hline 175 & 133 & -035 & 036 & 069 \\
\hline 200 & 100 & -099 & 004 & 066 \\
\hline 225 & 022 & -182 & -043 & 051 \\
\hline 250 & -056 & -285 & $\begin{array}{ll}-1 & 07\end{array}$ & 021 \\
\hline 275 & -181 & -409 & -189 & -026 \\
\hline 300 & -306 & -555 & -292 & -092 \\
\hline 325 & -430 & -724 & -416 & -181 \\
\hline 350 & -602 & -918 & -562 & -296 \\
\hline 375 & -819 & -1135 & -737 & -437 \\
\hline 400 & -990 & -1382 & -930 & -610 \\
\hline 425 & -1254 & -1655 & -1156 & -816 \\
\hline 450 & -1518 & -1956 & -1410 & -10.60 \\
\hline 475 & -1828 & -2286 & -1694 & -1340 \\
\hline 500 & -2184 & -2647 & -2011 & -1664 \\
\hline 525 & -2541 & -3040 & -2363 & -2030 \\
\hline 550 & -2943 & -3466 & -2750 & -2445 \\
\hline 575 & -3346 & -3925 & -3174 & -2909 \\
\hline 600 & -3841 & -4419 & -3637 & -3425 \\
\hline 625 & -4428 & -4949 & -4140 & -3998 \\
\hline 650 & -5016 & -5516 & -4685 & -4627 \\
\hline
\end{tabular}


TABLE XIII

Thermal Expansion of Crystal 240-C

\begin{tabular}{|c|c|c|c|c|}
\hline \multirow{3}{*}{$\begin{array}{l}\text { Temperature } \\
\qquad\left(t^{\circ} \mathrm{C}\right)\end{array}$} & \multicolumn{4}{|c|}{ Thermal Expansion $\times 10^{4}-\left(\frac{L_{t^{\circ} \mathrm{C}}-\mathrm{L}_{25^{\circ} \mathrm{C}}}{\mathrm{L}_{25^{\circ} \mathrm{C}}}\right)$} \\
\hline & \multirow{2}{*}{$\begin{array}{l}\text { From Dilatation } \\
\quad \text { Curve }\end{array}$} & \multicolumn{3}{|c|}{ Calculated from Principal Direction Expansions } \\
\hline & & $\begin{array}{l}\text { Single } \\
\text { Crystals }\end{array}$ & $\begin{array}{l}\text { Bridge, Schwartz } \\
\text { and Vaughan }(1)\end{array}$ & $\begin{array}{l}\text { Chrottı, Klepfer } \\
\text { and Wh1te }(2)\end{array}$ \\
\hline 25 & 000 & 000 & 000 & 000 \\
\hline 50 & 103 & 047 & 035 & 017 \\
\hline 75 & 206 & 073 & 066 & 040 \\
\hline 100 & 265 & 086 & 089 & 066 \\
\hline 125 & 279 & 084 & 103 & 091 \\
\hline 150 & 249 & 068 & 108 & 113 \\
\hline 175 & 175 & 035 & 102 & 130 \\
\hline 200 & 100 & -014 & 083 & 138 \\
\hline 225 & 026 & -082 & 049 & 137 \\
\hline 250 & -137 & -169 & -001 & 121 \\
\hline 275 & -212 & -276 & -068 & 089 \\
\hline 300 & -375 & -404 & -154 & 038 \\
\hline 325 & -494 & -555 & -260 & -034 \\
\hline 350 & -658 & -729 & -389 & -131 \\
\hline 375 & -821 & -927 & -540 & -254 \\
\hline 400 & -1029 & -1151 & -717 & -407 \\
\hline 425 & -1193 & -1400 & -921 & -592 \\
\hline 450 & -1446 & -1678 & -1152 & -813 \\
\hline 475 & -1698 & -1983 & -1412 & -1070 \\
\hline 500 & -2039 & -2318 & -1704 & -1369 \\
\hline 525 & -2380 & -2684 & -2030 & -1710 \\
\hline 550 & -2766 & $\begin{array}{lll}-30 & 81\end{array}$ & -2388 & -2097 \\
\hline 575 & -3240 & -3510 & -2782 & -2531 \\
\hline 600 & -3670 & -3973 & -3214 & -3017 \\
\hline 625 & -4100 & -4471 & -3683 & -3558 \\
\hline 650 & -4574 & -5004 & -4193 & -4153 \\
\hline
\end{tabular}


TABLE XIV

Thermal Expansions of Crystal $\mathrm{T}_{\mathrm{G}}$

\begin{tabular}{|c|c|c|c|c|}
\hline \multirow{3}{*}{$\begin{array}{l}\text { Temperature } \\
\left(t^{\circ} \mathrm{C}\right)\end{array}$} & \multicolumn{4}{|c|}{ Thermal Expansion $\times 10^{4}-\left(\frac{L_{t^{\circ}} \mathrm{C}=L_{25^{\circ}} \mathrm{C}}{L_{25^{\circ}} \mathrm{C}}\right)$} \\
\hline & \multirow{2}{*}{$\begin{array}{l}\text { From Dilatation } \\
\text { Curve }\end{array}$} & \multicolumn{3}{|c|}{ Calculated from Principal Direction Expansions } \\
\hline & & $\begin{array}{l}\text { Single } \\
\text { Crystals }\end{array}$ & $\begin{array}{c}\text { Bridge, Schwartz } \\
\text { and Vaughan }(1)\end{array}$ & $\begin{array}{l}\text { Chiotti, Klepfer } \\
\text { and White }(2)\end{array}$ \\
\hline 25 & 0.00 & 0.00 & 0.00 & 0.00 \\
\hline 50 & 0.15 & 0.40 & 0.28 & 0.11 \\
\hline 75 & 0.29 & 0.58 & 0.52 & 0.28 \\
\hline 100 & 0.26 & 0.63 & 0.68 & 0.47 \\
\hline 125 & 0.24 & 0.53 & 0.74 & 0.65 \\
\hline 150 & 0.03 & 0.27 & 0.72 & 0.80 \\
\hline 175 & -0.18 & -0.15 & 0.56 & 0.88 \\
\hline 200 & -0.73 & -0.75 & 0.28 & 0.88 \\
\hline 225 & -1.46 & -1.54 & -0.15 & 0.78 \\
\hline 250 & -2.20 & -2.52 & -0.74 & 0.52 \\
\hline 275 & -3.10 & -3.72 & -1.52 & 0.09 \\
\hline 300 & -4.36 & -5.14 & -2.50 & -0.52 \\
\hline 325 & -5.79 & -6.78 & -3.68 & -1.36 \\
\hline 350 & -7.75 & -8.66 & -5.09 & -2.46 \\
\hline 375 & -9.88 & -10.78 & -6.74 & -3.82 \\
\hline 400 & -12.01 & -13.19 & -8.66 & -5.49 \\
\hline 425 & -14.66 & -15.86 & -10.85 & -7.49 \\
\hline 450 & -17.32 & -18.81 & -13.33 & -9.86 \\
\hline 475 & -20.50 & -22.05 & -16.11 & -12.60 \\
\hline 500 & -23.51 & -25.59 & -19.21 & -15.76 \\
\hline 525 & -27.21 & -29.45 & -22.66 & -19.35 \\
\hline 550 & -31.44 & -33.62 & -26.45 & -23.42 \\
\hline 575 & -35.49 & -38.14 & -30.61 & -27.97 \\
\hline 600 & -39.83 & -43.00 & -35.16 & -33.05 \\
\hline 625 & -45.00 & -48.21 & -40.10 & -38.68 \\
\hline 650 & -50.62 & -53.79 & -45.46 & -44.88 \\
\hline
\end{tabular}


TABLE XV

Mean Thermal Expansion Coefficients of Alpha-Uranium in the [100] Direction

\begin{tabular}{|c|c|c|c|c|}
\hline \multirow{3}{*}{$\begin{array}{l}\text { Temperature } \\
\quad\left(t^{\circ} \mathrm{C}\right)\end{array}$} & \multicolumn{4}{|c|}{$\begin{array}{c}\text { Mean Thermal Expansion Coefficient Between } 20^{\circ} \text { and } t^{\circ} \times 10^{6}- \\
\left(\operatorname{per}^{\circ} \mathrm{C}\right)\end{array}$} \\
\hline & \multicolumn{3}{|c|}{ Calculated from Least Mean Square Fitted Equations } & \multirow{2}{*}{$\begin{array}{l}\text { Reported by } \\
\text { Lehr and } \\
\text { Langeron }(5,6)\end{array}$} \\
\hline & $\begin{array}{l}\text { Single Crystal } \\
\text { Expansion }\end{array}$ & $\begin{array}{l}\text { Bridge, Schwartz } \\
\text { and Vaughan(l) }\end{array}$ & $\begin{array}{l}\text { Chiott1, Klepfer } \\
\text { and White }(2)\end{array}$ & \\
\hline 50 & 245 & 234 & 203 & \\
\hline 75 & 249 & 237 & 209 & \\
\hline 100 & 253 & 241 & 216 & \\
\hline 125 & 257 & 245 & 222 & \\
\hline 150 & 261 & 249 & 229 & \\
\hline 175 & 265 & 253 & 235 & \\
\hline 200 & 270 & 258 & 241 & 224 \\
\hline 225 & 274 & 262 & 248 & \\
\hline 250 & 279 & 267 & 254 & 231 \\
\hline 275 & 284 & 272 & 261 & \\
\hline 300 & 289 & 277 & 267 & 238 \\
\hline 325 & 294 & 282 & 273 & 242 \\
\hline 350 & 299 & 288 & 280 & \\
\hline 375 & 304 & 294 & 286 & \\
\hline 400 & 310 & 300 & 292 & 255 \\
\hline 425 & 315 & 306 & 299 & \\
\hline 450 & 321 & 312 & 305 & \\
\hline 475 & 326 & 319 & 312 & 271 \\
\hline 500 & 332 & 325 & 318 & 277 \\
\hline 525 & 338 & 332 & 325 & \\
\hline 550 & 345 & 339 & 331 & 290 \\
\hline 575 & 351 & 346 & 337 & \\
\hline 600 & 357 & 354 & 344 & 305 \\
\hline 625 & 364 & 362 & 350 & 313 \\
\hline 650 & 370 & 369 & 357 & \\
\hline
\end{tabular}


TABLE XVI

Mean Thermal Expansion Coefficients of Alpha-Uranium in the [010] Direction

$$
\left(\alpha[010] 20^{\circ} \mathrm{C} \text { to } \mathrm{t}^{\circ} \mathrm{C}=\frac{\mathrm{L}_{\mathrm{t}^{\circ} \mathrm{C}}-\mathrm{L}_{20^{\circ} \mathrm{C}}}{\mathrm{L}_{20^{\circ} \mathrm{C}}\left(\mathrm{t}^{\circ} \mathrm{C}-20^{\circ} \mathrm{C}\right)}\right)
$$

\begin{tabular}{|c|c|c|c|c|}
\hline \multirow{3}{*}{$\begin{array}{l}\text { Temperature } \\
\quad\left(t^{\circ} \mathrm{C}\right)\end{array}$} & \multicolumn{4}{|c|}{$\begin{array}{l}\text { Mean Thermal Expansion Coefficient Between } 20^{\circ} \text { and } t^{\circ} \mathrm{C} \times 10^{6}- \\
\left(\text { per }{ }^{\circ} \mathrm{C}\right)\end{array}$} \\
\hline & \multicolumn{3}{|c|}{ Calculated from Least Mean Square Fitted Equations } & \multirow{2}{*}{$\begin{array}{l}\text { Reported by } \\
\text { Lehr and } \\
\text { Langeron }(5,6)\end{array}$} \\
\hline & $\begin{array}{l}\text { Single Crystal } \\
\text { Expansion }\end{array}$ & $\begin{array}{l}\text { Bridge, Schwartz } \\
\text { and Vaughan }(1)\end{array}$ & $\begin{array}{l}\text { Chiotti, Klepfer } \\
\text { and White( } 2)\end{array}$ & \\
\hline 50 & 0.5 & 0.4 & -0.3 & \\
\hline 75 & 0.2 & 0.2 & -0.2 & \\
\hline 100 & -0.2 & 0.1 & -0.1 & \\
\hline 125 & -0.4 & -0.1 & -0.1 & \\
\hline 150 & -0.7 & -0.2 & -0.1 & \\
\hline 175 & -1.1 & -0.5 & -0.2 & \\
\hline 200 & -1.4 & -0.7 & -0.3 & 0.2 \\
\hline 225 & -1.8 & -1.0 & -0.5 & \\
\hline 250 & -2.2 & -1.2 & -0.6 & -0.3 \\
\hline 275 & -2.6 & -1.6 & -0.9 & \\
\hline 300 & -2.9 & -1.9 & -1.1 & -1.0 \\
\hline 325 & -3.4 & -2.2 & -1.4 & -1.3 \\
\hline 350 & -3.9 & -2.6 & -1.8 & \\
\hline 375 & -4.3 & -3.0 & -2.1 & \\
\hline 400 & -4.8 & -3.4 & -2.5 & -2.5 \\
\hline 425 & -5.3 & -3.9 & -3.0 & \\
\hline 450 & -5.8 & -4.3 & -3.5 & \\
\hline 475 & -6.3 & -4.8 & -4.0 & -3.9 \\
\hline 500 & -6.8 & -5.3 & -4.5 & -4.4 \\
\hline 525 & -7.4 & -5.8 & -5.1 & \\
\hline 550 & -7.9 & -6.4 & -5.8 & -5.5 \\
\hline 575 & -8.5 & -7.0 & -6.4 & \\
\hline 600 & -9.1 & -7.6 & -7.2 & -6.7 \\
\hline 625 & -9.7 & -8.2 & -7.9 & -7.5 \\
\hline 650 & -10.3 & -8.8 & -8.7 & \\
\hline
\end{tabular}


TABLE XVII

Mean Thermal Expansion Coefficients of Alpha-Uranium in the [001] Direction

$$
\left(\alpha_{[001] 20^{\circ} \mathrm{C} \text { to } t^{\circ} \mathrm{C}}=\frac{\mathrm{L}_{t^{\circ} \mathrm{C}}-\mathrm{L}_{20^{\circ} \mathrm{C}}}{\mathrm{L}_{20^{\circ} \mathrm{C}}\left(t^{\circ} \mathrm{C}-20^{\circ} \mathrm{C}\right)}\right)
$$

\begin{tabular}{|c|c|c|c|c|}
\hline \multirow{3}{*}{$\begin{array}{l}\text { Temperature } \\
\left(t^{\circ} \mathrm{C}\right)\end{array}$} & \multicolumn{4}{|c|}{$\begin{array}{l}\text { Mean Thermal Expansion Coefficient } \\
\text { Between } 20^{\circ} \text { and } t^{\circ} \mathrm{C} \times 10^{6}-\left(\text { per }{ }^{\circ} \mathrm{C}\right)\end{array}$} \\
\hline & \multicolumn{3}{|c|}{$\begin{array}{l}\text { Calculated from Least Mean } \\
\text { Square Fitted Equations }\end{array}$} & \multirow{2}{*}{$\begin{array}{c}\text { Reported by } \\
\text { Lehr and } \\
\text { Langeron }(5,6)\end{array}$} \\
\hline & $\begin{array}{l}\text { Single Crystal } \\
\text { Expansion }\end{array}$ & $\begin{array}{l}\text { Bridge, Schwartz } \\
\text { and Vaughan }(1)\end{array}$ & $\begin{array}{l}\text { Chiott1, Klepfer } \\
\text { and White }(2)\end{array}$ & \\
\hline 50 & 209 & 198 & 168 & \\
\hline 75 & 214 & 200 & 173 & \\
\hline 100 & 220 & 203 & 179 & \\
\hline 125 & 226 & 206 & 185 & \\
\hline 150 & 231 & 209 & 191 & \\
\hline 175 & 237 & 212 & 197 & \\
\hline 200 & 243 & 215 & 203 & 215 \\
\hline 225 & 248 & 220 & 209 & \\
\hline 250 & 254 & 224 & 215 & 226 \\
\hline 275 & 260 & 229 & 221 & \\
\hline 300 & 266 & 234 & 227 & 237 \\
\hline 325 & 272 & 239 & 233 & 243 \\
\hline 350 & 278 & 244 & 239 & \\
\hline 375 & 284 & 250 & 245 & \\
\hline 400 & 289 & 256 & 250 & 262 \\
\hline 425 & 296 & 263 & 256 & \\
\hline 450 & 302 & 269 & 262 & \\
\hline 475 & 308 & 276 & 268 & 282 \\
\hline 500 & 314 & 284 & 274 & 289 \\
\hline 525 & 321 & 291 & 280 & \\
\hline 550 & 327 & 299 & 286 & 304 \\
\hline 575 & 333 & 307 & 292 & \\
\hline 600 & 340 & 315 & 298 & 322 \\
\hline 625 & 346 & 324 & 304 & 333 \\
\hline 650 & 353 & 333 & 310 & \\
\hline
\end{tabular}


TABLE XVIII

Volumetric Mean Thermal Expansion Coefficients of Alpha Uranium $\left(a_{\mathrm{v} 20^{\circ}}\right.$ to $\left.t^{\circ} \mathrm{C}=\frac{\mathrm{v}_{t^{\circ} \mathrm{C}}-\mathrm{v}_{20^{\circ} \mathrm{C}}}{\mathrm{v}_{20^{\circ} \mathrm{C}\left(\mathrm{t}^{\circ} \mathrm{C}-20^{\circ} \mathrm{C}\right)}}\right)$

\begin{tabular}{|c|c|c|c|c|}
\hline \multirow{3}{*}{$\begin{array}{l}\text { Temperature } \\
\quad\left(t^{\circ} \mathrm{C}\right)\end{array}$} & \multicolumn{4}{|c|}{$\begin{array}{c}\text { Volumetric Mean Thermal Expansion Coefficient } \\
\text { Between } 20^{\circ} \mathrm{C} \text { and } t^{\circ} \mathrm{C} \times 10^{6}-\left(p_{\mathrm{r}}{ }^{\circ} \mathrm{C}\right)\end{array}$} \\
\hline & \multicolumn{3}{|c|}{$\begin{array}{l}\text { Calculated from Least Mean } \\
\text { Square Fitted Equations }\end{array}$} & \multirow{2}{*}{$\begin{array}{c}\text { Reported by } \\
\text { Lehr and } \\
\text { Langeron } *(5,6)\end{array}$} \\
\hline & $\begin{array}{l}\text { Single Crystal } \\
\text { Expansion }\end{array}$ & $\begin{array}{l}\text { Bridge, Schwartz } \\
\text { and Vaughan }(1)\end{array}$ & $\begin{array}{l}\text { Chiott1, Klepfer } \\
\text { and White }(2)\end{array}$ & \\
\hline 50 & 458 & 443 & 366 & \\
\hline 75 & 465 & 448 & 379 & \\
\hline 100 & 472 & 453 & 393 & \\
\hline 125 & 479 & 459 & 405 & \\
\hline 150 & 485 & 465 & 418 & \\
\hline 175 & 492 & 471 & 430 & \\
\hline 200 & 499 & 477 & 441 & 444 \\
\hline 225 & 506 & 483 & 452 & \\
\hline 250 & 512 & 490 & 463 & 455 \\
\hline 275 & 519 & 496 & 473 & \\
\hline 300 & 526 & 503 & 484 & 468 \\
\hline 325 & 533 & 510 & 493 & 472 \\
\hline 350 & 540 & 518 & 503 & \\
\hline 375 & 547 & 525 & 511 & \\
\hline 400 & 554 & 533 & 519 & 489 \\
\hline 425 & 561 & 540 & 528 & \\
\hline 450 & 568 & 548 & 536 & \\
\hline 475 & 575 & 556 & 543 & 508 \\
\hline 500 & 582 & 565 & 550 & 516 \\
\hline 525 & 589 & 573 & 556 & \\
\hline 550 & 596 & 582 & 562 & 531 \\
\hline 575 & 603 & 591 & 568 & \\
\hline 600 & 610 & 600 & 573 & 549 \\
\hline 625 & 617 & 609 & 578 & 558 \\
\hline 650 & 624 & 619 & 583 & \\
\hline
\end{tabular}

*Volumetric mean thermal expansion coefficients reported are three times the linear mean thermal expansion coefficient of randomly oriented polycrystalline materıal 
TABLE XIX

Corrected Alpha-Uranium Lattice Parameters at $25^{\circ} \mathrm{C}$

\begin{tabular}{|c|c|c|}
\hline \multirow{2}{*}{$\begin{array}{c}\text { Lattice } \\
\text { Parameter }\end{array}$} & $\begin{array}{c}|c| \\
\text { Bridge, Schwartz } \\
\text { and Vaughan* }\end{array}$ & $\begin{array}{c}\text { Single Crystal } \\
\text { Expansion** }\end{array}$ \\
\cline { 2 - 3 } & 28528 & 28527 \\
$a_{0}-(\AA)$ & 58672 & 58725 \\
$b_{0}-(\AA)$ & 49566 & 49507 \\
$c_{0}-(\AA)$ & 82945 & 82920 \\
$V-\left(\AA^{3}\right)$ & \\
\hline
\end{tabular}

* Lattice parameters at $25^{\circ} \mathrm{C}$ calculated from least mean square equations fitted to data of Bridge, Schwartz and Vaughan (1)

**Lattice parameters at $25^{\circ} \mathrm{C}$ calculated from least mean square equations $f_{1}$ tted to single crystal expansion data and assuming the respective lattice parameters at $650^{\circ} \mathrm{C}$ as given by equations fitted to data of Bridge et al are correct 
Figure 1

ALPHA-URANIUM $a_{0}$ LATTICE PARAMETER VARIATION WITH TEMPERATURE

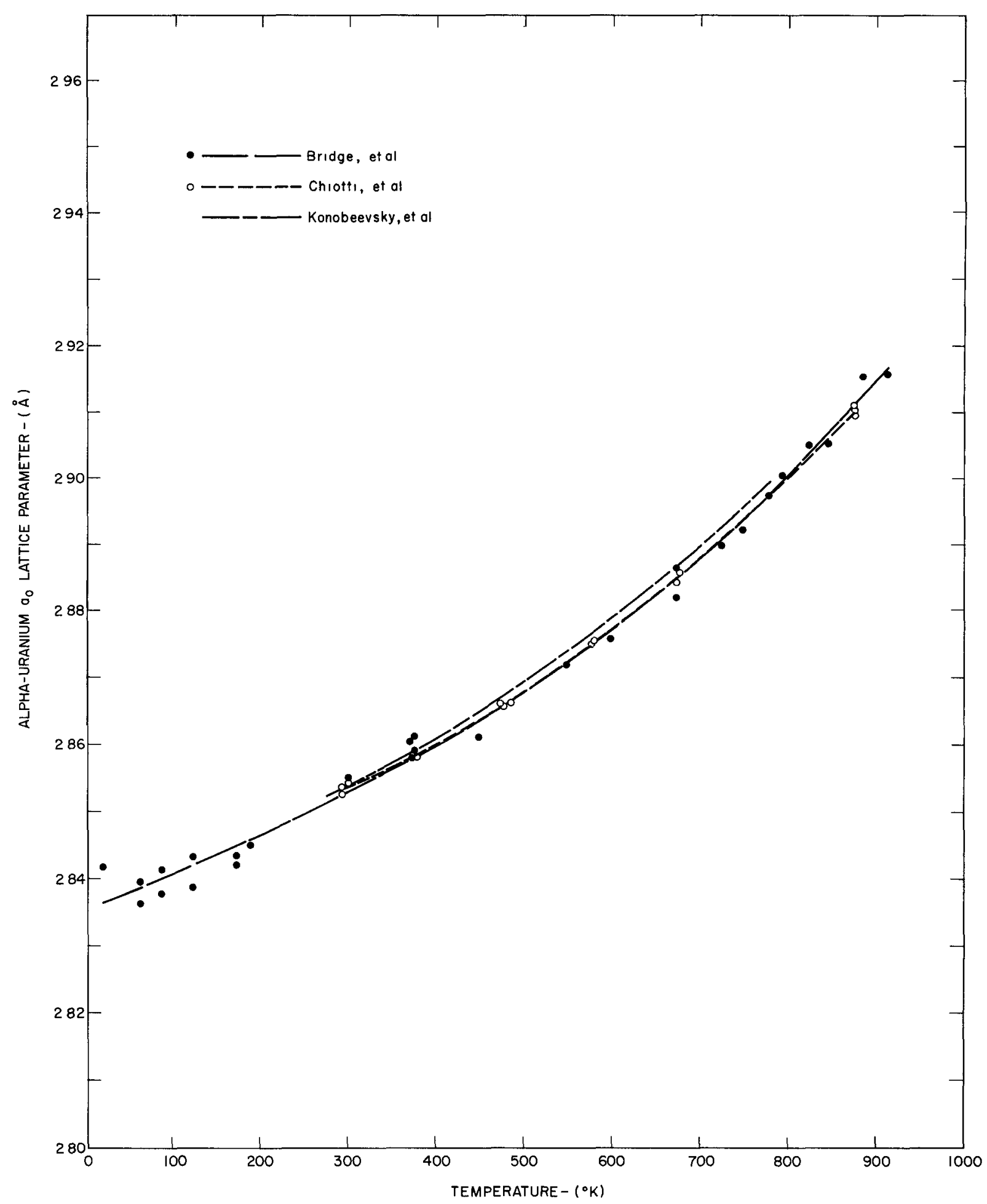


Figure 2

ALPHA-URANIUM $b_{O}$ LATTICE PARAMETER VARIATION WITH TEMPERATURE

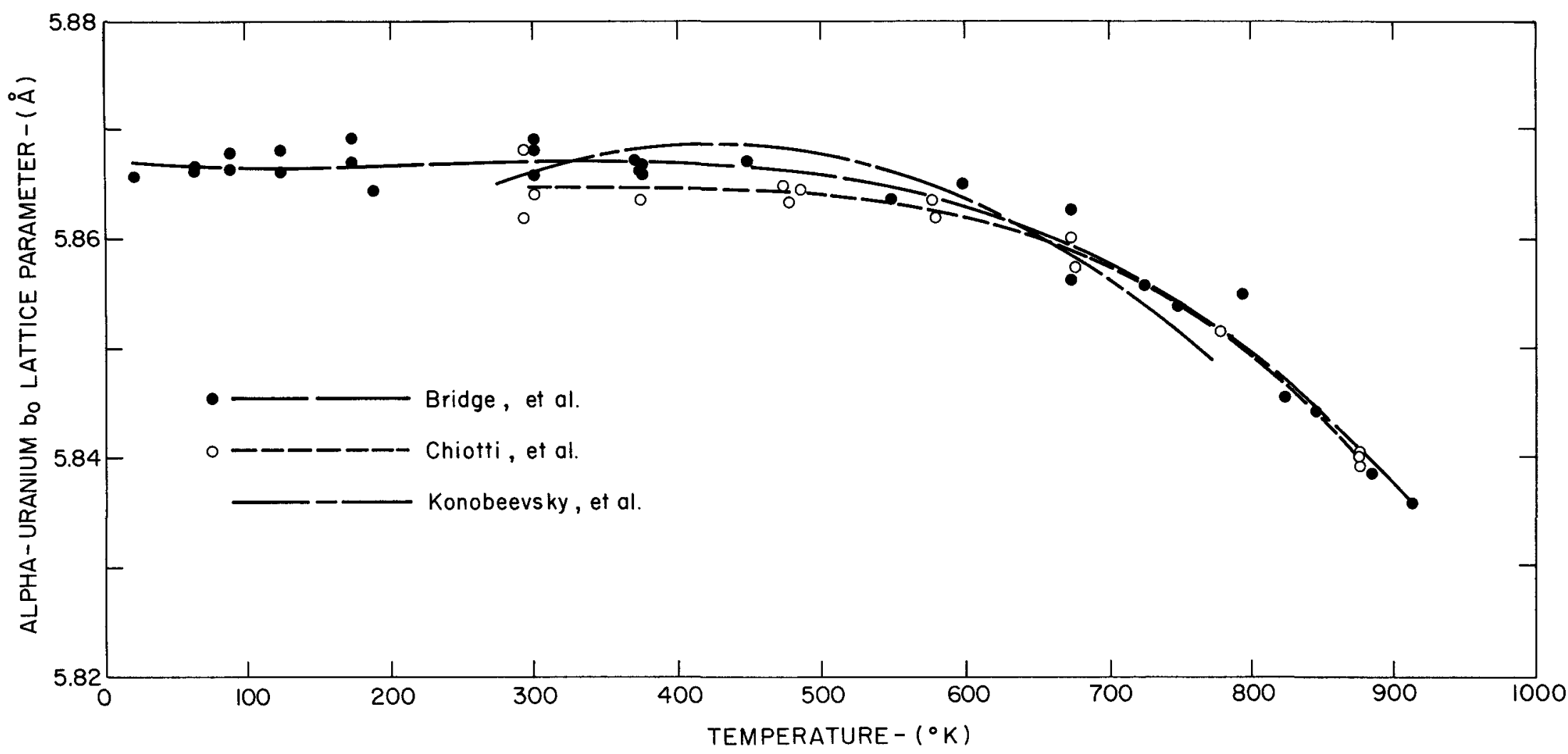


Figure 3

ALPHA-URANIUM $c_{0}$ LATTICE PARAMETER VARIATION WITH TEMPERATURE

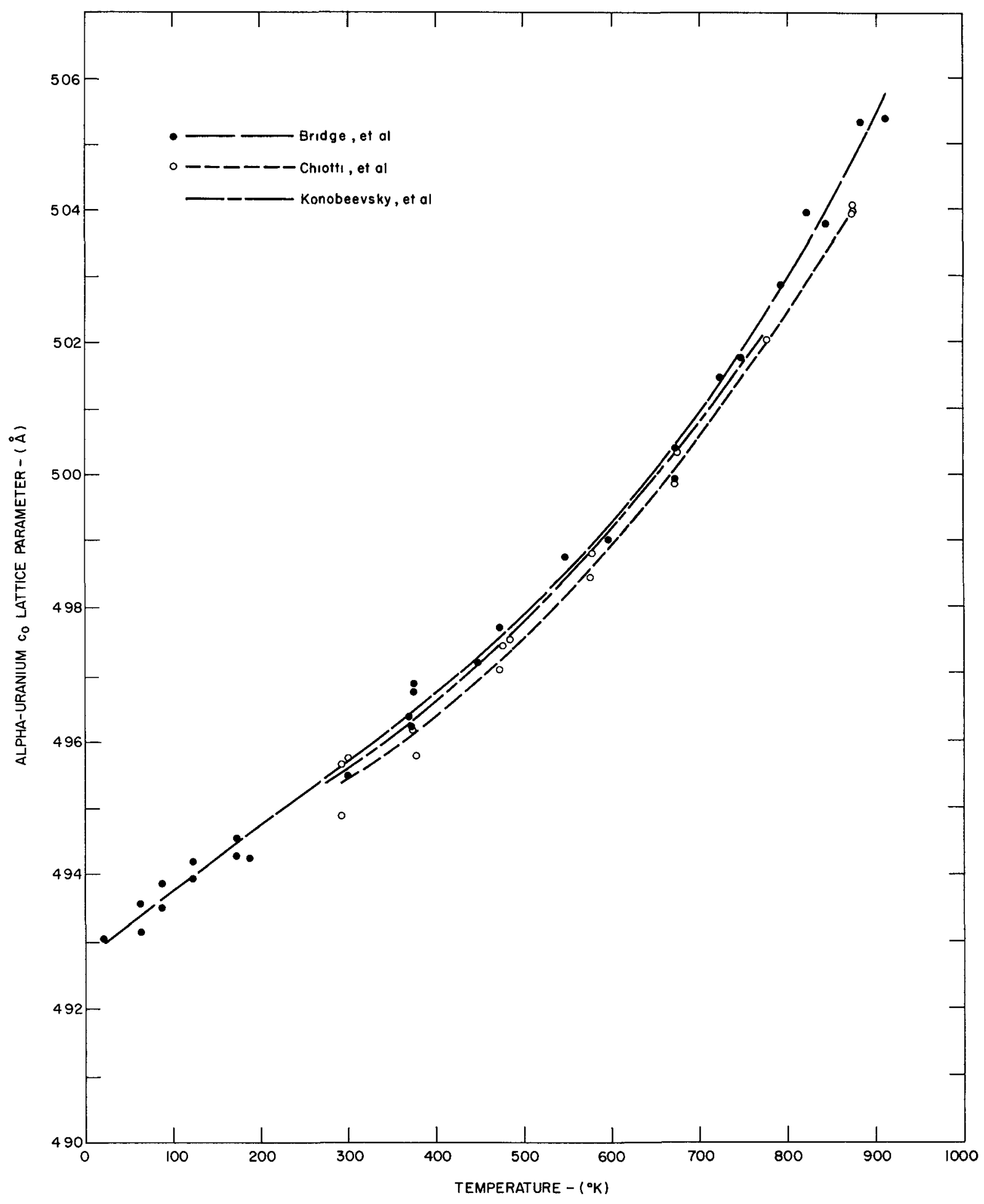


Figure 4

ALPHA-URANIUM UNIT CELL VOLUME VARIATION WITH TEMPERATURE

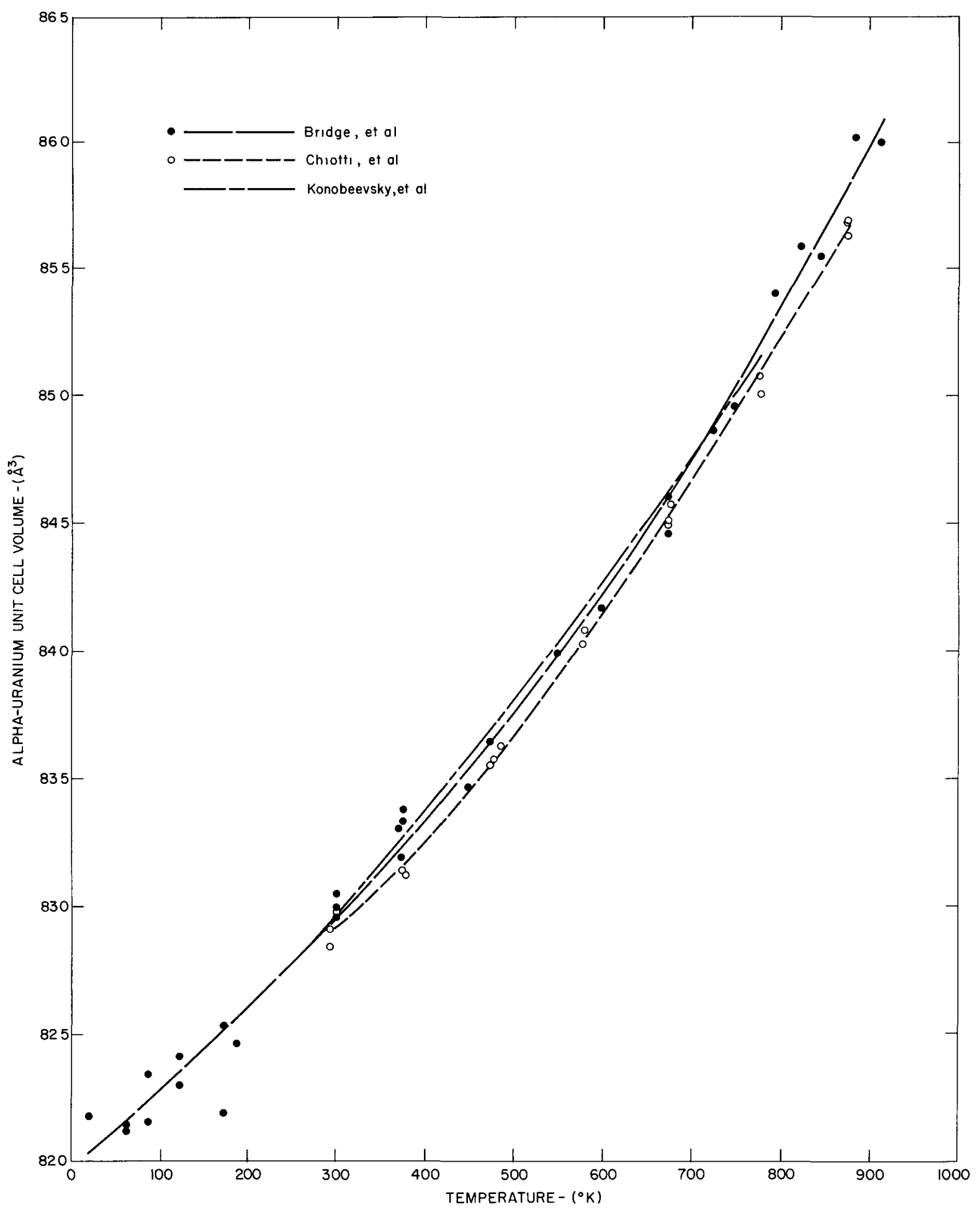


Figure 5

THERMAL EXPANSION OF ALPHA-URANIUM IN THE [100] DIRECTION

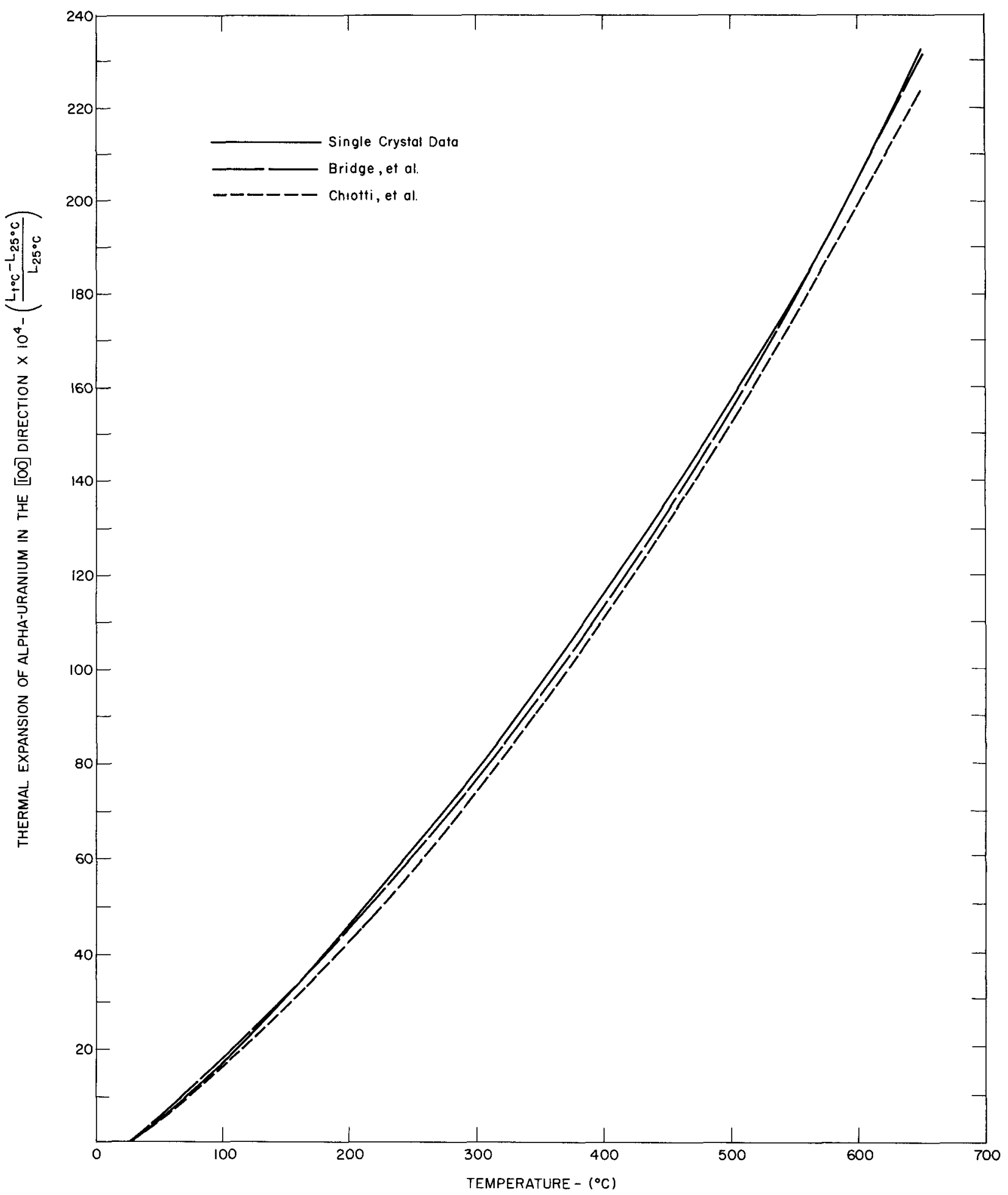


Figure 6

THERMAL EXPANSION OF ALPHA-URANIUM IN THE [OIO] DIRECTION

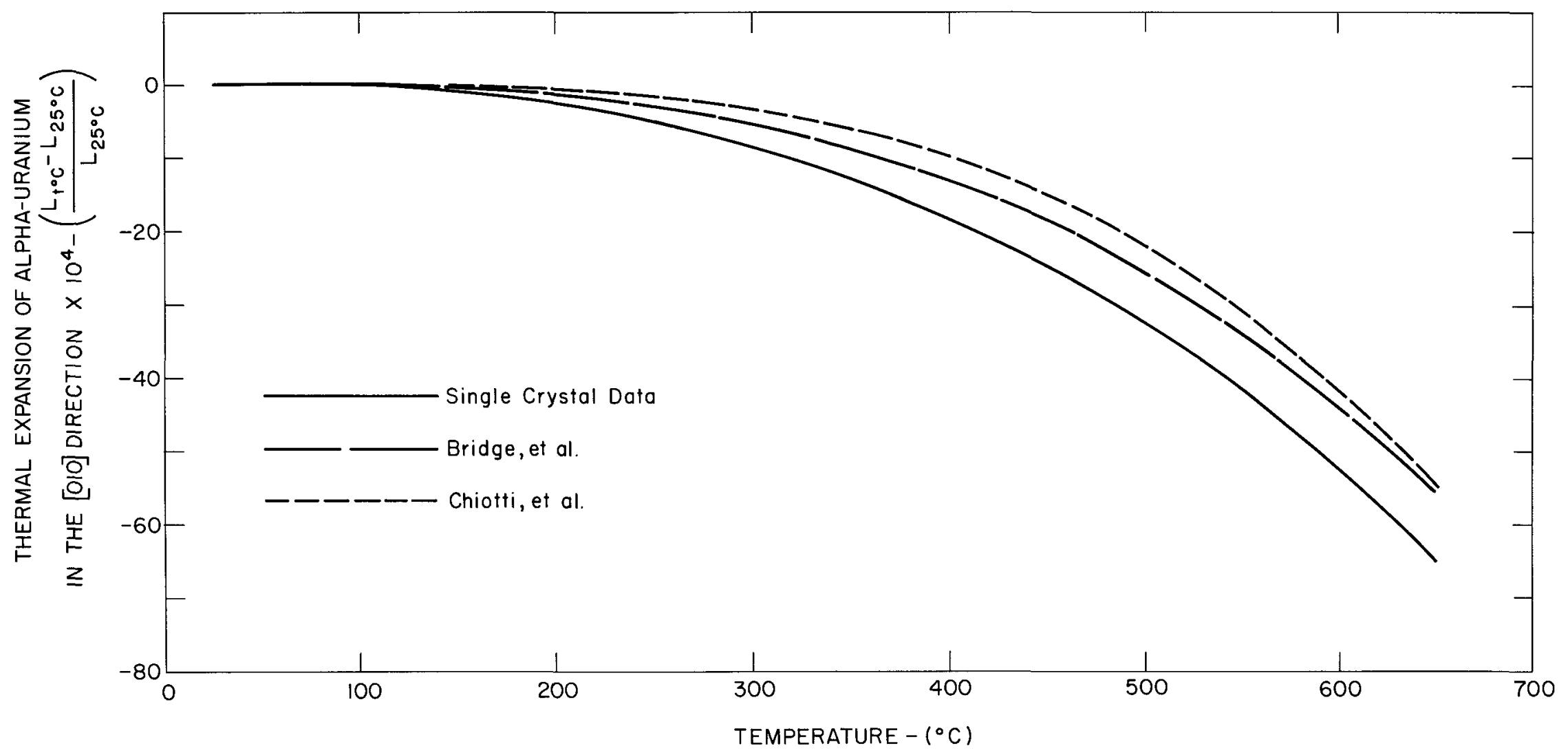


Figure 7

THERMAL EXPANSION OF ALPHA-URANIUM IN THE [OOI] DIRECTION

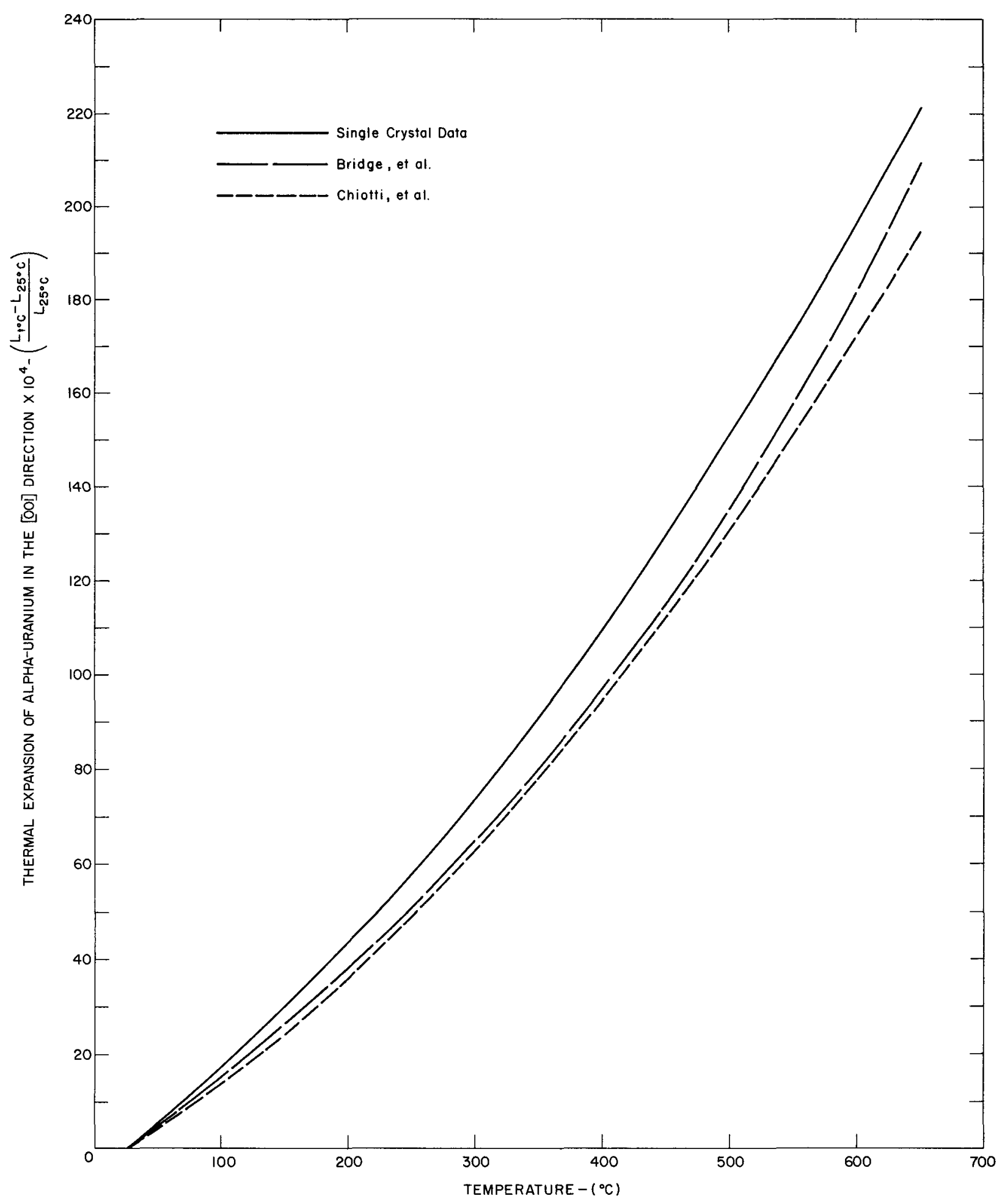


Figure 8

VOLUMETRIC THERMAL EXPANSION OF ALPHA-URANIUM

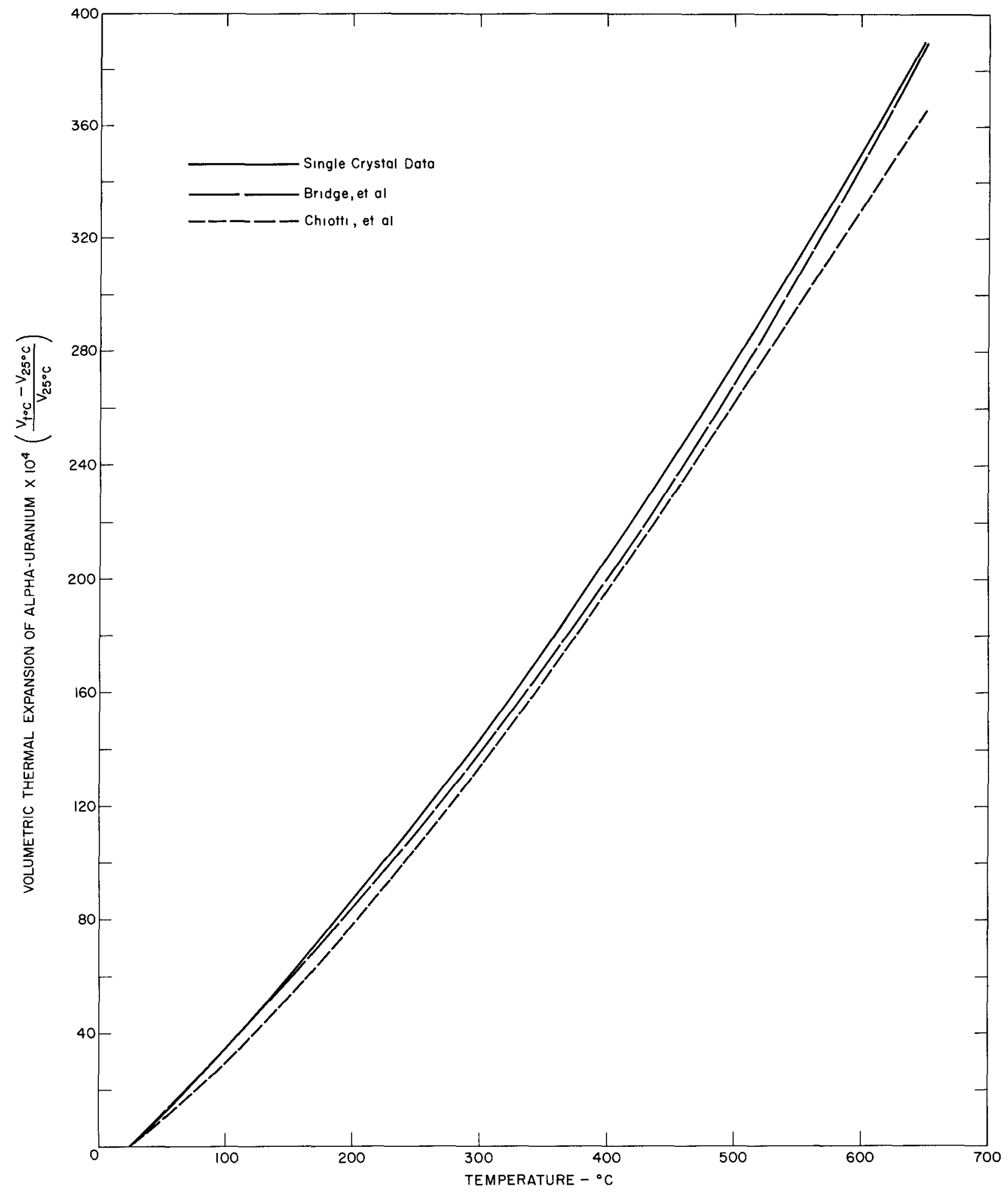


Figure 9

THERMAL EXPANSION OF CRYSTAL 219-2

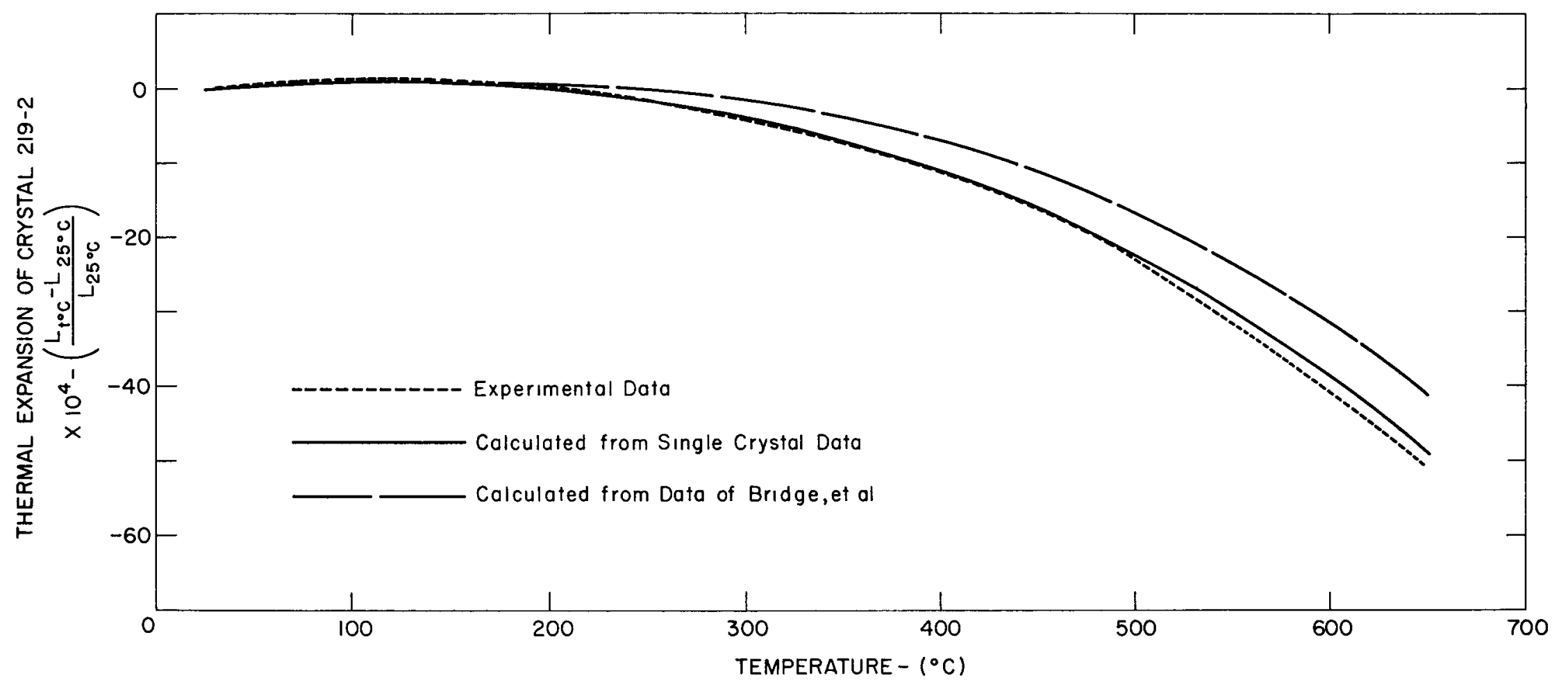


Figure 10

THERMAL EXPANSION OF CRYSTAL 235-B

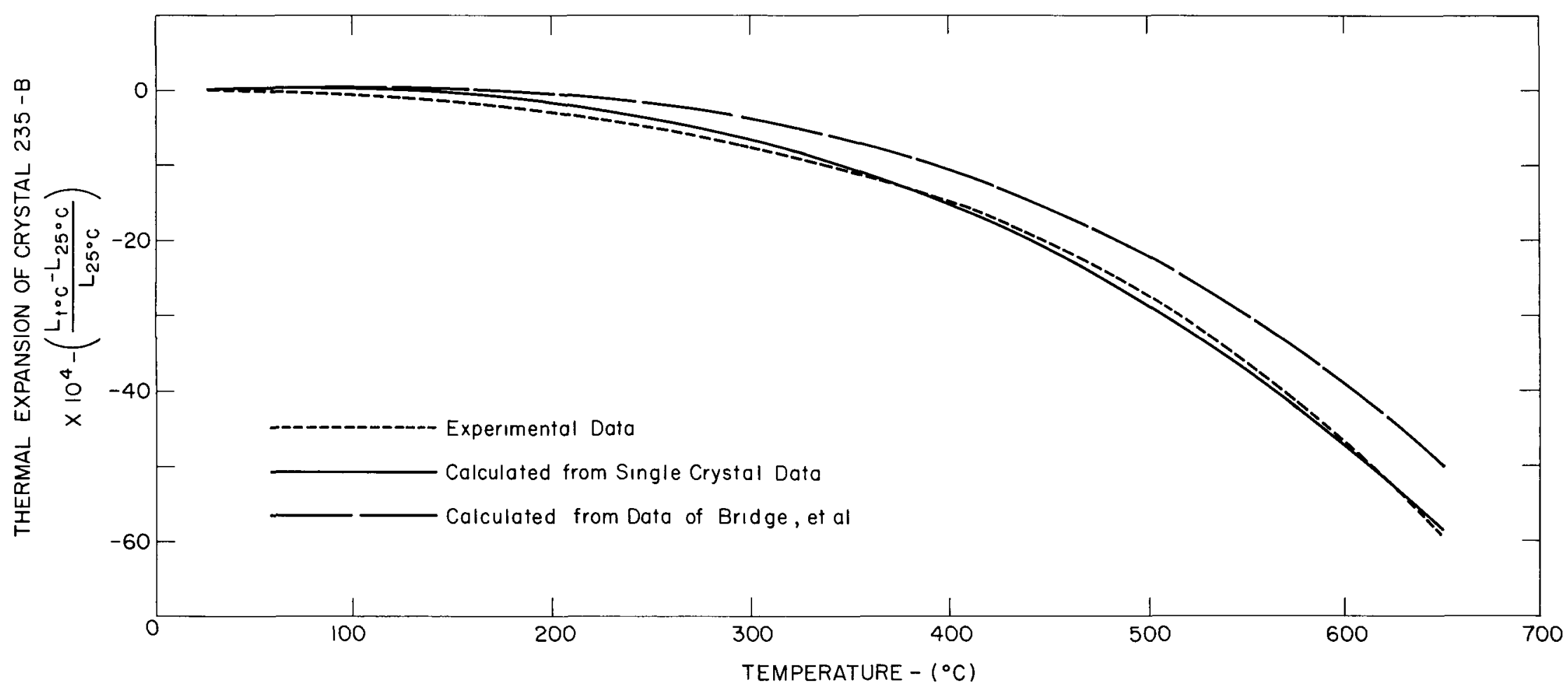


Figure 11

THERMAL EXPANSION OF CRYSTAL 240-A

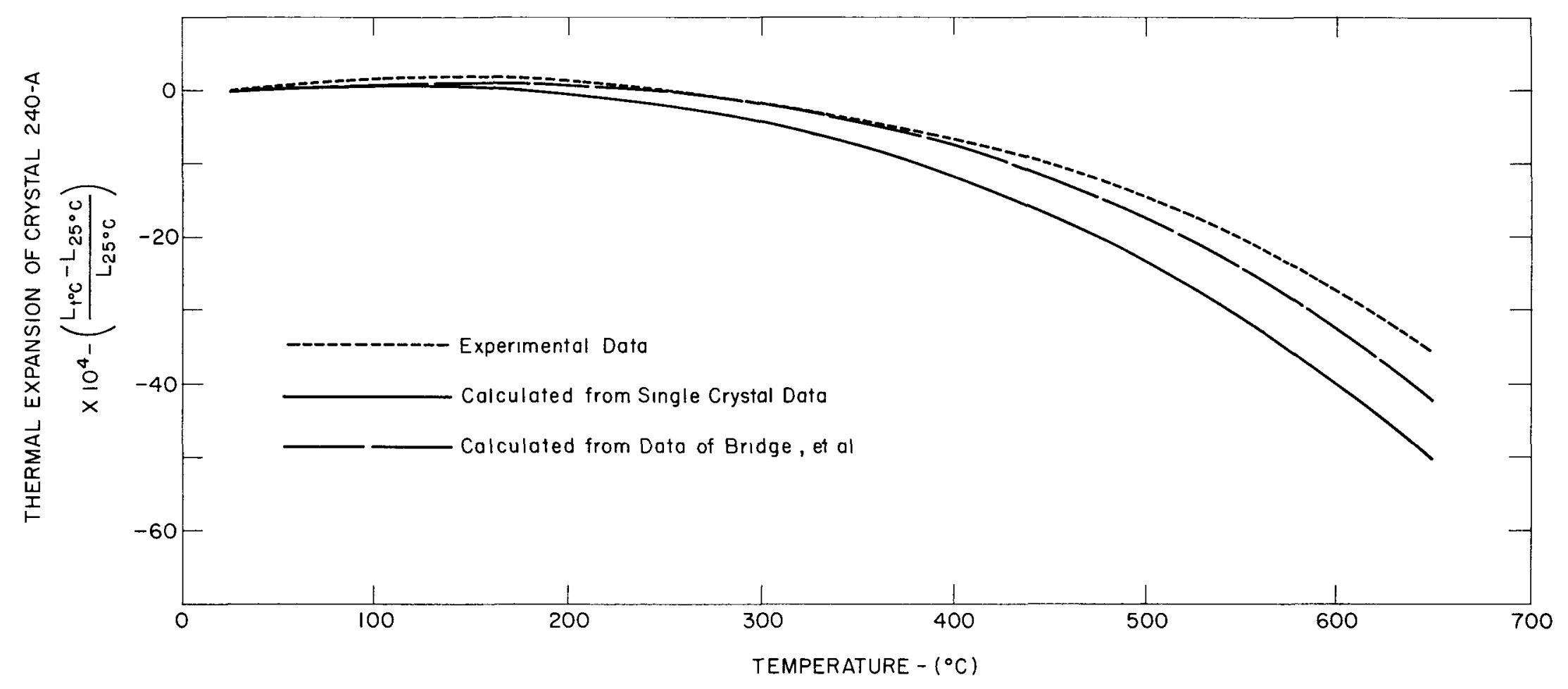


Figure 12

THERMAL EXPANSION OF CRYSTAL 240-B

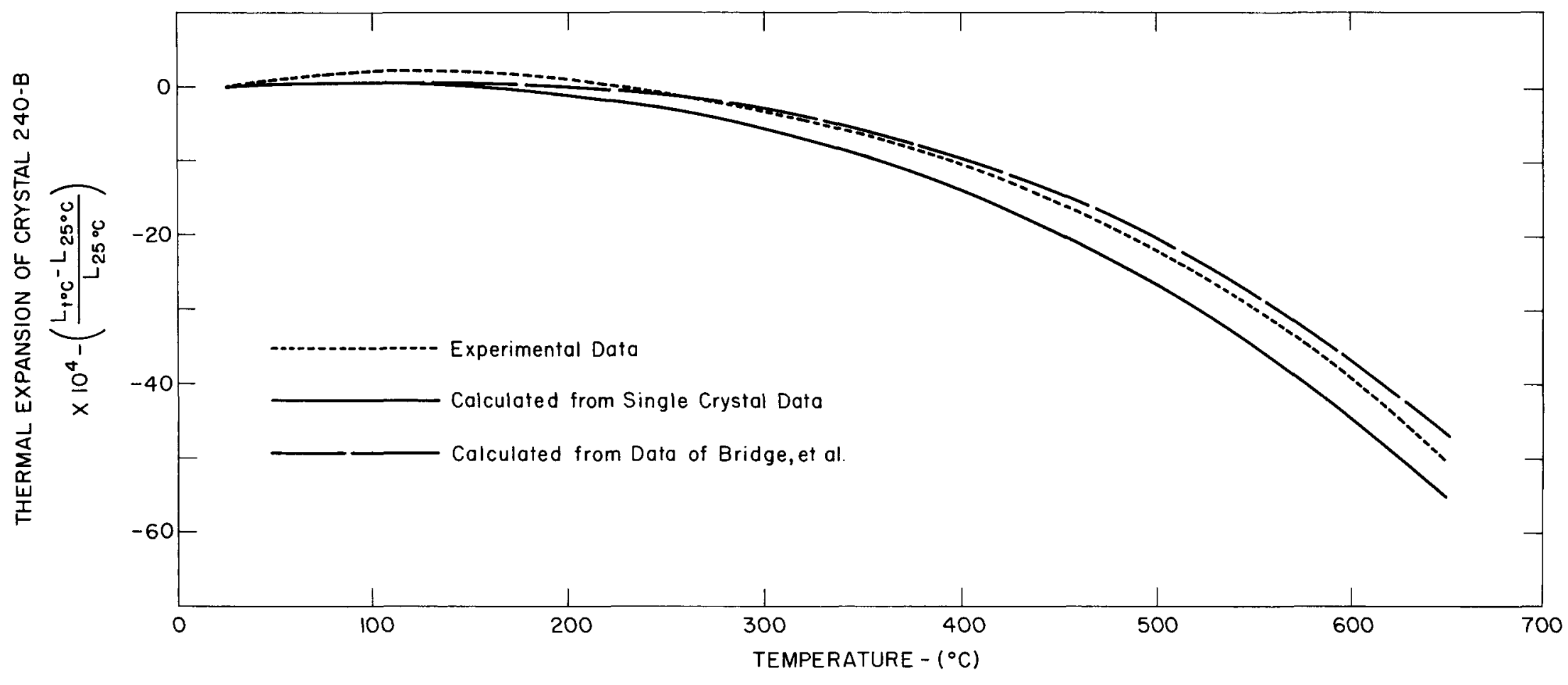


Figure 13

THERMAL EXPANSION OF CRYSTAL 240-C

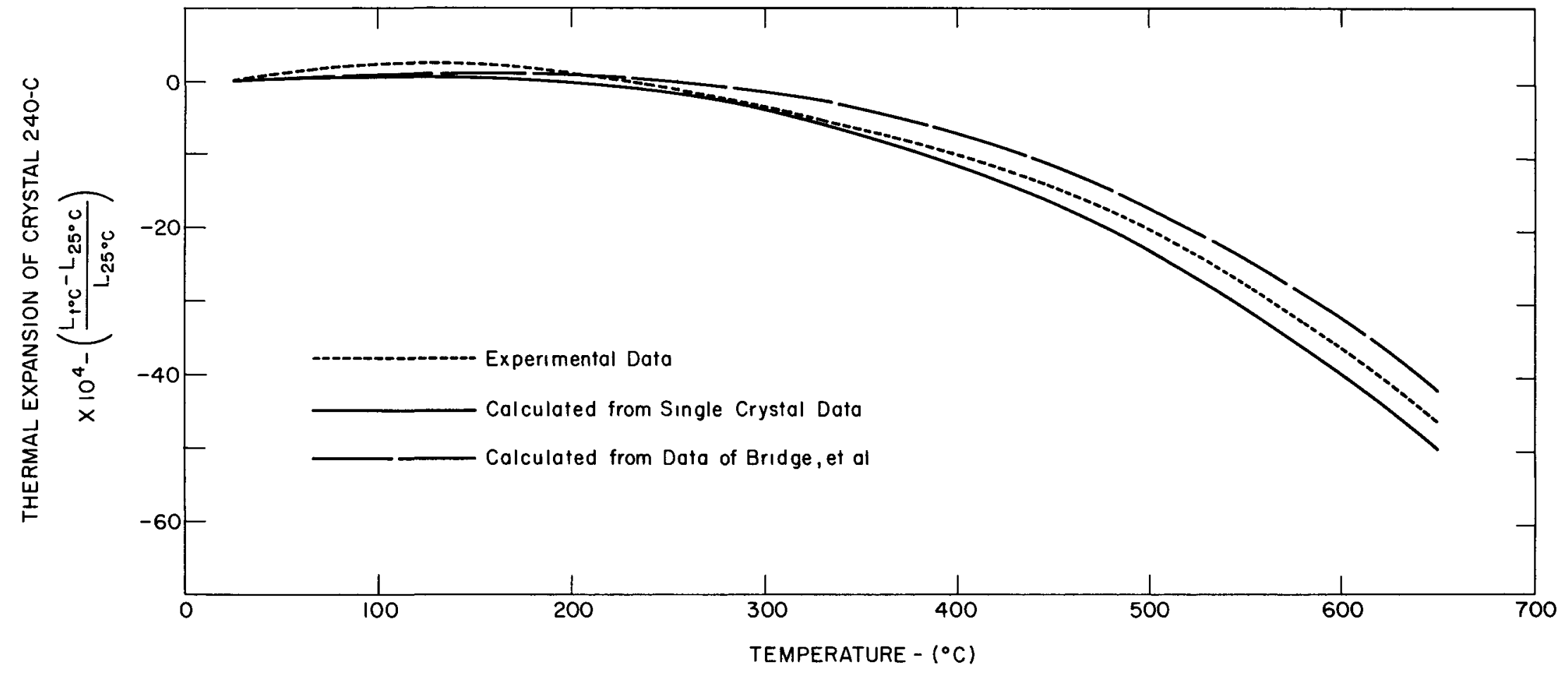


Figure 14

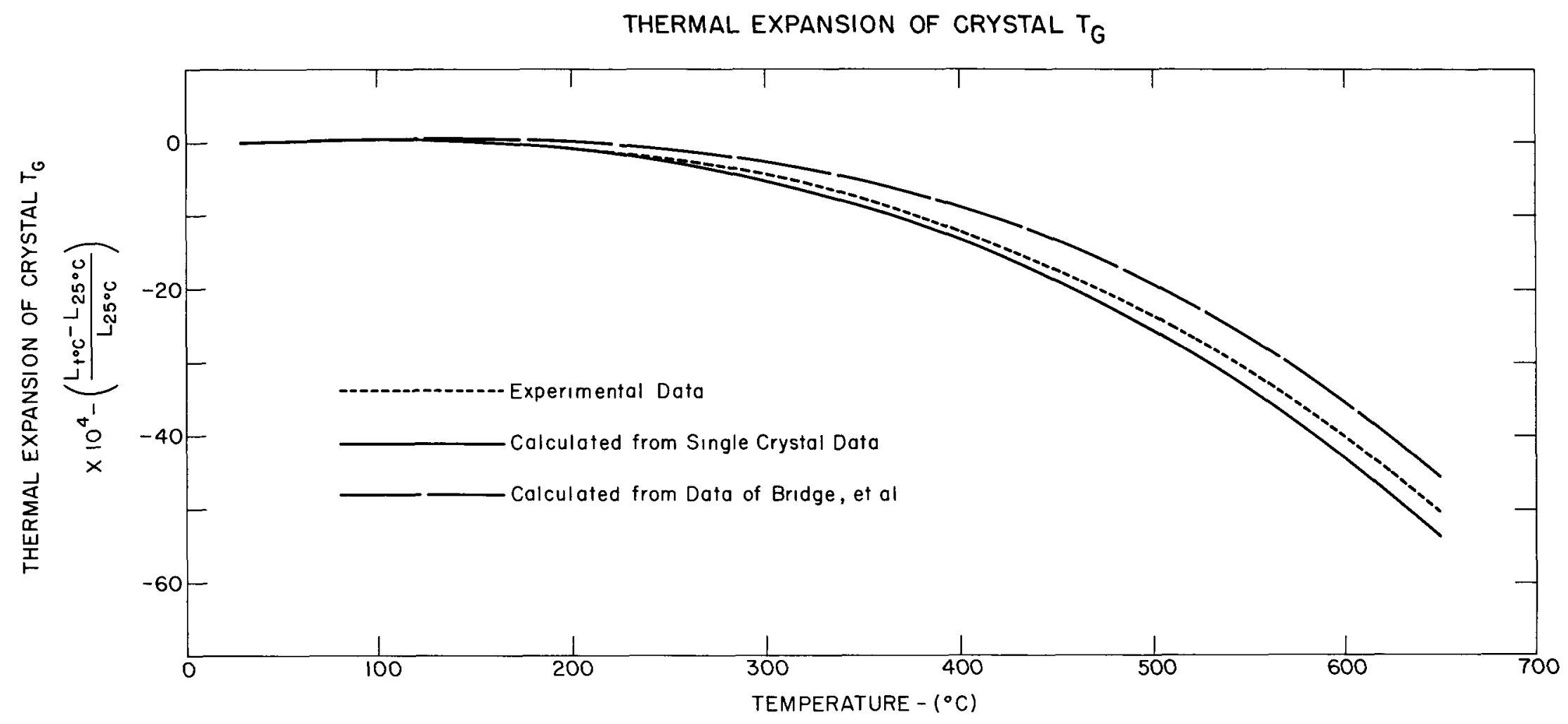

